THE ROLE OF ADDITIONAL NON-EPS FORECASTS: EVIDENCE USING PRE-TAX FORECASTS

by

Landon Mauler

A Dissertation Submitted to the Faculty of the

\title{
DEPARTMENT OF MANAGEMENT
}

In Partial Fulfillment of the Requirements

For the Degree of

DOCTOR OF PHILOSOPHY

WITH A MAJOR IN ACCOUNTING

In the Graduate College

THE UNIVERSITY OF ARIZONA

2013 


\section{THE UNIVERSITY OF ARIZONA GRADUATE COLLEGE}

As members of the Dissertation Committee, we certify that we have read the dissertation prepared by Landon Mauler, titled "The Role of Additional Non-EPS Forecasts:

Evidence Using Pre-Tax Forecasts" and recommend that it be accepted as fulfilling the dissertation requirement for the Degree of Doctor of Philosophy.

Date: (3-19-2013)

Dan S. Dhaliwal

Date: (3-19-2013)

Mark A. Trombley

Date: (3-19-2013)

Jayanthi Sunder

Date: (3-19-2013)

Lubomir Litov

Final approval and acceptance of this dissertation is contingent upon the candidate's submission of the final copies of the dissertation to the Graduate College.

I hereby certify that I have read this dissertation prepared under my direction and recommend that it be accepted as fulfilling the dissertation requirement.

Dissertation Director: Dan S. Dhaliwal

Date: (3-19-2013) 


\section{STATEMENT BY AUTHOR}

This dissertation has been submitted in partial fulfillment of requirements for an advanced degree at the University of Arizona and is deposited in the University Library to be made available to borrowers under rules of the Library.

Brief quotations from this dissertation are allowable without special permission, provided that accurate acknowledgment of source is made. Requests for permission for extended quotation from or reproduction of this manuscript in whole or in part may be granted by the head of the major department or the Dean of the Graduate College when in his or her judgment the proposed use of the material is in the interests of scholarship. In all other instances, however, permission must be obtained from the author.

SIGNED: Landon Mark Mauler 


\section{ACKNOWLEDGEMENTS}

I am grateful for the helpful comments and suggestions of Dan Dhaliwal (committee chair), Lubomir Litov, Jayanthi Sunder, and Mark Trombley. I also wish to thank John Campbell, Dane Christensen, Katherine Drake, David Kenchington, Tom Klein, and Phil Lamoreaux for their assistance. I also thank participants at the University of Arizona, the University of Oklahoma, the University of Georgia, the University of Alberta, Florida State University, and Vanderbilt University, as well as participants at the 2012 Brigham Young University Accounting Symposium for their comments. Finally, I gratefully acknowledge financial support from the Deloitte Foundation's Doctoral Fellowship Program. 


\section{TABLE OF CONTENTS}

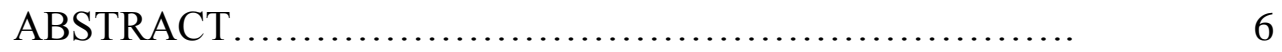

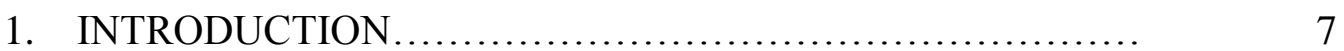

2. BACKGROUND AND HYPOTHESIS DEVELOPMENT.... 15

2.1 Disaggregated Analyst Forecasts............................ 15

2.2 Determinants of Pre-Tax Earnings Forecast Coverage.......... 16

2.3 Investor Use of Pre-Tax Earnings Forecasts.................. 17

2.4 Effect of Pre-Tax Earnings Forecasts on the Transparency of Tax-related Earnings Management......................... 19

2.5 Effect of Pre-Tax Earnings Forecasts on Firm-level Tax Avoidance.............................................. 21

3. RESEARCH DESIGN ..................................... 23

4. DATA AND RESULTS ................................. 31

4.1 Results on the Determinants of Pre-Tax Earnings Forecast

Coverage.......................................................................... 31

4.2 Results on Investor Use of Pre-Tax Earnings Forecasts........ 33

4.3 Results on the Effect of Pre-Tax Earnings Forecasts on the Transparency of Tax-related Earnings Management.......... 37

4.4 Results on the Effect of Pre-Tax Earnings Forecasts on Firm-level Tax Avoidance............................... 40

5. CONCLUSION ......................................... 43

APPENDIX A: FIGURES..................................... 45

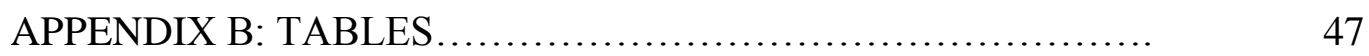

REFERENCES ........................................... 58 


\begin{abstract}
In this study, I examine whether and how analysts' pre-tax earnings forecasts are informative to investors. Specifically, I first examine the determinants of pre-tax forecast coverage and whether pre-tax forecasts are incrementally informative to investors in evaluating firm performance. Next, I examine whether pre-tax forecasts decrease the transparency of tax-related earnings management. Lastly, I examine how pre-tax earnings forecasts influence management's incentives to avoid taxes. Using $\mathrm{I} / \mathrm{B} / \mathrm{E} / \mathrm{S}$ data from 2002-2011, I find pre-tax forecast coverage is associated with firm-level tax characteristics. In addition, I find investors utilize pre-tax earnings forecasts in evaluating firm performance, after controlling for after-tax earnings forecasts. In addition, the results of this study indicate investors more significantly discount earnings which have been managed through the tax account when pre-tax earnings forecasts are available, consistent with increased transparency resulting from detailed forecasting. Lastly, I find some evidence that increases in pre-tax forecast coverage are associated with a decrease in tax avoidance. This result is consistent with a change in management's incentives resulting from the existence of additional performance benchmarks. Collectively, this study provides evidence that pre-tax earnings forecasts are informative in multiple settings. These findings have important implications for academics and practitioners in understanding the role of additional non-EPS income statement forecasts.
\end{abstract}




\section{INTRODUCTION}

Financial analysts play an important role in producing firm-specific information for investors. ${ }^{1}$ Recently, the dissemination of detailed income statement line-item analyst forecasts has become more prevalent. This study extends prior research by examining the information content of these additional forecasts. Specifically, I focus on pre-tax earnings forecasts, which allow investors to parse out the income tax expense from underlying operating performance. I begin by examining the determinants of analyst pretax coverage. I then ask three questions regarding the information content of pre-tax earnings forecasts. First, I examine whether pre-tax forecasts are incrementally informative to investors regarding firm performance. Secondly, I examine how pre-tax earnings forecast coverage affects the transparency of earnings management through the tax expense account. Finally, I examine whether pre-tax forecasts impact management's incentives regarding tax avoidance.

The results of this study suggest analysts' pre-tax earnings forecast disclosure is associated with investor demand regarding tax-related information. In addition, results suggest pre-tax forecasts are an informative performance benchmark, decrease the effectiveness of earnings management through the tax account, and are associated with decreases in tax avoidance. This study provides evidence that investors utilize additional non-EPS income statement forecasts in multiple settings and that detailed analyst forecasts influence management incentives. In addition, this study provides insight into analysts' ability to provide account-specific information to investors through detailed,

\footnotetext{
${ }^{1}$ While a large stream of literature has examined the impact of analysts' forecasts, these studies almost exclusively focus on after-tax (EPS) earnings (Ramnath et al. (2008) provides one such review).
} 
income statement line-item forecasts. Over the past decade, the availability of many disaggregated forecasts, including pre-tax earnings forecasts, has increased drastically. ${ }^{2}$ While many disaggregated forecasts are available from analysts, this study focuses on pre-tax earnings forecasts for multiple reasons. Unlike other disaggregated forecasts, such as forecasts of operating income, pre-tax earnings forecasts provide implicit forecasts of a single income statement account; income tax expense. Prior literature has provided evidence that tax information in the financial statements contains value-relevant information (Graham et al. 2012). However, the role of analysts in providing tax-related information remains unclear. The complex and subjective nature of the tax account increases the likelihood that investors look to analysts for additional tax-related information. In addition, prior literature suggests pre-tax earnings are more persistent than after-tax earnings (Schmidt, 2006). Finally, many contracts are based on pre-tax income. ${ }^{3}$ These reasons suggest the forecast of pre-tax earnings is an ideal candidate to examine whether additional disaggregated income statement forecasts are informative with regard to evaluating firm performance, increasing the transparency of individual accounts, and influencing management incentives.

Over the past decade, the prevalence of analysts' pre-tax earnings forecasts through I/B/E/S has increased dramatically (see Figure 1), ${ }^{4}$ but little is known about their information content. While prior research has examined the determinants to cash flow

\footnotetext{
${ }^{2}$ In 2001, there were 56,664 unique one-year non-EPS forecasts in I/B/E/S. That increased to $1,411,171$ unique one-year non-EPS forecasts in $\mathrm{I} / \mathrm{B} / \mathrm{E} / \mathrm{S}$ in 2011. During this time period, the number of firms receiving pre-tax forecast coverage also increased from 1,031 to 3,500.

${ }^{3}$ Dyreng (2007) finds pre-tax measures of income (primarily EBITDA) is used in debt covenants and Gaertner (2011) finds pre-tax income is frequently used in managers' compensation contracts.

${ }^{4}$ As Figure 1 indicates, the percentage of firms with after-tax earnings forecast coverage which also receive pre-tax earnings forecast coverage increases from less than $10 \%$ in 2002 to over $60 \%$ in 2010.
} 
forecasts, my first research question examines the determinants of the dissemination of pre-tax forecasts. I examine the determinants of pre-tax earnings forecasts for two reasons. First, mixed evidence has been provided regarding the determinants of non-EPS forecasts (e.g., DeFond and Hung (2003), Givoly et al. (2009)). Second, because pre-tax coverage is not random, I use the determinants of pre-tax forecast coverage to address the issue of self-selection in subsequent analyses. My next research question examines whether pre-tax forecasts are viewed by investors as an additional, and incremental, earnings benchmark. This question builds on the work of Rees and Sivaramakrishnan (2007) by examining whether investors consider specific expenses in evaluating firm performance. If investors view the tax expense account as noisy and subjective, I predict they will value a firm's ability to meet/beat its pre-tax earnings target. ${ }^{5}$

Next, I examine how tax-related forecasts impact the effectiveness of earnings management through the tax expense account. Dhaliwal et al. (2004) and Cook et al. (2008) find that firms manage the tax expense account to meet analysts' after-tax earnings forecasts. Gleason and Mills (2008) examine the market reaction to this form of earnings management and find investors significantly discount the reward for beating analysts' forecasts through the manipulation of the tax expense account. I examine whether investors' reaction to the management of earnings through the tax expense account is impacted by the availability of analysts' tax-related forecasts. Because taxrelated forecasts are likely to increase the transparency of the tax expense account, I posit

\footnotetext{
${ }^{5}$ The impact of taxes on earnings is also frequently mentioned in earnings announcements. One example comes from Ford's 2011 earnings announcement which states, in part, "Full year 2011 net income was $\$ 20.2$ billion, or $\$ 4.94$ per share, an increase of $\$ 13.7$ billion, or $\$ 3.28$ per share, from a year ago. The results include a favorable one-time, non-cash special item of $\$ 12.4$ billion for the release of almost all of the valuation allowance against the company’s net deferred tax assets." (Ford 2012)
} 
that investors will more significantly discount earnings management through the tax expense account when analysts' tax-related forecasts are available.

As investors use analysts' forecasts to evaluate firm performance, the dissemination of additional non-EPS forecasts is expected to have an effect on management incentives. Specifically, if investors respond to pre-tax income forecasts by evaluating a firm, in part, on pre-tax earnings, management's incentives pertaining to pretax earnings, as well as the tax expense account, are likely to be impacted. A growing number of studies have responded to the call by Shackelford and Shevlin (2001) for evidence explaining what drives tax avoidance decisions. While studies have identified many factors which result in higher levels of tax avoidance, it remains unclear why more firms do not engage in higher levels of tax avoidance (e.g., Weisbach 2002). Increased monitoring and scrutiny by government regulators are associated with lower levels of tax avoidance (Hoopes et al. 2012). As pre-tax earnings forecasts provide an implicit forecast of the income tax expense account, this additional forecast should also result in additional awareness and scrutiny regarding a firm's level of tax avoidance. If additional analyst coverage results in increased scrutiny, I expect initiations in pre-tax coverage to be negatively associated with changes in tax avoidance.

With respect to my first research question, I find firm-level tax characteristics are significant determinants of the dissemination of pre-tax forecasts, consistent with the 'demand hypothesis' outlined by DeFond and Hung (2003). I then find investors value tax-related forecasts provided by analysts. Specifically, my results suggest investors' reactions to a firm's ability to meet after-tax earnings benchmarks are impacted by 
whether or not a firm also meets (misses) its pre-tax earnings benchmark. In addition, I find the market reward to earnings managed through the tax account is discounted more significantly when tax-related forecasts are provided. I perform additional analyses addressing self-selection and these results remain consistent. Lastly, I find initiations in analysts' pre-tax coverage are associated with decreases in tax avoidance. Overall, this study suggests analysts' pre-tax forecasts are informative to investors for multiple reasons. More specifically, these tax-related forecasts impact investors' perceptions of firm performance, increase the transparency of earnings management through the tax expense account, and also impact management incentives with respect to the tax expense account.

This study contributes to the literature in three ways. First, this study adds to the growing literature regarding the determinants of non-EPS forecast coverage by analysts. As previously mentioned, there is mixed evidence surrounding the issuance of additional forecasts. Specifically, there is debate about whether disaggregated forecasts are issued when investors demand additional information (known as the 'demand hypothesis'). As disaggregated forecast are becoming more common, understanding their determinants is an important issue. My results provide evidence consistent with the 'demand hypothesis.' More specifically, I find that pre-tax forecast coverage is higher when the volatility of the tax expense is higher, book-tax differences are larger, and the effective tax rate is lower, all consistent with analysts responding to investor demand for additional information regarding the tax expense account. 
Second, the results provide evidence of the importance of pre-tax earnings to investors. In a recent study, Robinson (2010) finds that firms incur additional economic costs in an attempt to avoid reductions in pre-tax earnings. In her study, Robinson discusses "a need for additional research into why firms care about pre-tax earnings..." (p. 641). In addition, pre-tax earnings, along with the impact of specific tax items on overall firm performance, are frequently discussed in earnings announcements. In instances where tax-related issues have a material impact on after-tax earnings, investors likely view pre-tax and after-tax earnings differently. My results suggest, for firms with pre-tax analyst coverage, investors are concerned with a firm's ability to meet/beat its pre-tax earnings benchmarks. These results provide support for the notion that pre-tax earnings matter, at least in part, because pre-tax earnings are an important part of measuring, and interpreting, firm performance.

Third, this paper adds to the growing literature examining the information content of disaggregated (non-EPS) forecasts. Over the past decade, researchers have begun to focus on non-EPS forecasts such as cash flow forecasts and sales forecasts. ${ }^{6}$ However, the evidence regarding the information content of disaggregated forecasts is fairly nacent and contains mixed results (e.g., Givoly et al., 2009). A recent paper by McInnis and Collins (2011) examines whether the presence of cash flow forecasts increases the transparency of managing earnings through accrual manipulations. While McInnis and Collins (2011) find cash flow forecast coverage is associated with increased accrual

\footnotetext{
${ }^{6}$ Studies that examine cash flow forecasts include, but are not limited to, DeFond and Hung (2003) and Call et al. (2009). Studies which examine revenue forecasts include, among others, Keung (2010) and Ertimur et al. (2011).
} 
quality, I provide evidence regarding the ability of specific income statement line-item forecasts to increase the transparency of an individual account. While similar in spirit, my results provide evidence consistent with analysts increasing the transparency of specific accounts by disseminating detailed, line-item forecasts.

Fourth, this paper provides additional evidence on whether detailed forecasts impact management incentives. If analysts' pre-tax earnings forecasts lead investors to weigh pre-tax earnings as a performance signal, relatively less effort is expected in maximizing after-tax income. In addition, if pre-tax forecasts do enhance the transparency of the tax expense account, firms with high levels of tax avoidance would be exposed to additional scrutiny from investors and regulators. While prior research has confirmed that managers attempt to meet analysts' after-tax earnings forecasts, additional disaggregated forecasts represent additional benchmarks which managers are expected to meet. My results suggest managers who face pre-tax earnings benchmarks exercise greater caution regarding tax avoidance, consistent with this additional benchmark altering management incentives.

Overall, my evidence suggests there is reason to believe analysts' tax-related forecasts are informative and credible signals. Consequently, market participants may look to analysts' tax-related forecasts for additional information. This study examines how market participants use and respond to the explicit pre-tax forecast and the implicit forecast of the tax expense account.

The rest of the paper is organized as follows. In Section 2, I discuss background information about and develop my hypotheses. In Section 3, I outline the models and 
research methodology used to test each hypothesis. In Section 4, I describe the sample and discuss the results. I conclude in Section 5. 


\section{BACKGROUND AND HYPOTHESIS DEVELOPMENT}

\subsection{Disaggregated Analyst Forecasts}

Analysts' aggregate, after-tax (EPS) forecasts have been available for several decades. However, in the past several years, analysts have begun to voluntarily disseminate additional forecasts. While many of these are not related to the income statement (such as Cash Flows from Operations, Enterprise Value, and Funds from Operations), other forecasts represent sections or components of the income statement. For example, analysts have disclosed revenue, gross margin, operating income, EBITDA, EBIT, and pre-tax income forecasts. While the frequency of these forecasts varies widely, these additional forecasts are becoming more common. While $\mathrm{I} / \mathrm{B} / \mathrm{E} / \mathrm{S}$ has made it a priority to obtain and disclose additional forecasts, the decision of whether to disclose additional forecasts is made at the analyst and brokerage level.

Very little is known about analysts' ability to forecast specific line items such as the tax expense account. Prior studies indicate analysts struggle to incorporate taxrelated information into forecasts (e.g., Plumlee, 2003 and Chen and Schoderbek, 2000). However, anecdotal evidence suggests tax forecasts are not naïve. In discussions with a tax partner who provides consulting to several analysts, he described two ways in which analysts attempt to understand tax issues and make effective tax forecasts. First, although he readily admitted financial analysts themselves often have very little understanding about taxes, he described how many brokerages provide a list of tax experts to their analysts. When analysts encounter difficult or complex tax transactions, they are able to contact these tax experts for explanations about the transactions or issues in question and 
for understanding regarding the implications on future performance. In addition, the tax partner also indicated there are some situations where analysts will forecast the income statement up until pre-tax earnings. Then, the analyst will send him (the tax expert) his/her forecast and ask for a forecast of the income tax expense account. Therefore, while analysts may not be tax experts, they have the resources to make, or obtain, wellinformed tax expense forecasts.

\subsection{Determinants of Pre-Tax Earnings Forecast Coverage}

Prior studies have provided limited evidence exists suggesting additional forecasts are issued, at least in part, in response to investor demand. Early of this is provided by DeFond and Hung (2003). In their study, they examine the determinants of cash flow forecasts and find firm-level characterstics (e.g., earnings volatility, financial health, size of accruals) are associated with the propensity to receive cash flow forecasts. This evidence is consistent with the 'demand hypothesis' which predicts analysts provide additional forecasts when investors demand them. However, a recent paper by Givoly et al. (2009) calls into question the demand hypothesis. More specifically, Givoly et al. (2009) finds cash flow forecasts are less accurate than earnings forecasts and they appear to be naïve extensions of earnings forecasts. Both of these findings lead the authors to question the validity of the demand hypothesis. While Call et al. (2012) dispute some of the conclusions made by Givoly et al. (2009), additional evidence regarding the demand hypothesis is warranted. To contribute to this discussion, I examine the determinants of pre-tax forecast coverage. It is important to note that the decision to issue pre-tax earnings forecasts is different than the decision to issue cash flow forecasts. All analysts 
who issue (after-tax) earnings forecasts implicitly forecast pre-tax earnings. As a result, the decision to disclose pre-tax earnings forecasts requires no additional effort. With regards to cash flow forecasts, analysts must put forth additional effort as cash flow forecasts are not implicity forecasted within the income statement. As providing additional forecasts, such as pre-tax earnings forecasts, increases the transparency of an analyst's forecasting process, I expect analysts to issue this additional information only when it is demanded. Consequently, I predict analysts' decision to disclose pre-tax forecasts is associated with investor demand (the 'demand hypothesis').

\section{H1: The propensity for pre-tax earnings coverage is associated with firm-}

\section{level investor demand.}

\subsection{Investor Use of Pre-Tax Earnings Forecasts}

While I am not able to directly measure investor demand, I assume investor demand for tax information is associated with firm-level tax characteristics. Therefore, I examine the association between pre-tax earnings forecasts and firm-level tax characteristics. The determinants of pre-tax forecast coverage are also used to address self-selection issues in later empirical analyses. I recognize that pre-tax earnings forecasts are not issued randomly; as a result, I control for self-selection in subsequent analyses where I am interested in the impact of pre-tax coverage.

There is a rich stream of literature focusing on analysts' forecasts of after-tax earnings. Because of the lack of available disaggregated forecasts, less is known about whether investors use additional line-item forecasts, such as pre-tax earnings forecasts, to further evaluate firm performance. Notable exceptions are Ertimur et al. (2003) and Rees 
and Siviramakrishnan (2007) which examine market reactions to revenue forecasts. Ertimur et al. (2003) find investors' value revenue surprises more than expense surprises. However, they do not examine how individual expenses are valued. In fact, they expect revenue surprises to be of higher value because 'the expense surprise is noisier because it is an aggregate of different expenses and changes' (p. 186). In addition, Rees and Siviramakrishnan (2007) examine the acts of meeting earnings and revenue forecasts and find the market places the greatest premium (discount) when the two signals are consistent. This study extends prior studies by examining whether investors weigh an individual expense (income taxes) in evaluating firm performance.

As previously mentioned, Robinson (2010) finds that firms incur economic costs in an attempt to avoid reductions in pre-tax earnings. In her study, Robinson discusses "a need for additional research into why firms care about pre-tax earnings and whether their belief that pre-tax earnings matter more than after-tax earnings is attributable to performance measurement, stock price performance, contracting, or political costs" (p. 641). Pre-tax income is expected to be incrementally informative about firm performance for multiple reasons. First, as mentioned above, the results of Robinson (2010) suggest managers focus on pre-tax earnings. As a result, rational investors will evaluate management, in part, based on pre-tax performance. With explicit pre-tax earnings forecasts provided, investors can better evaluate actual pre-tax earnings. Second, prior studies have generally indicated pre-tax earnings are more persistent than after-tax earnings. Prior literature also indicates investors generally place greater weight on components of earnings with greater levels of persistence (Lipe 1986). As a result, a 
portion of investor attention is expected to be directed towards pre-tax earnings when evaluating current firm performance and future expectations. Third, because many investors perceive the tax expense account to be complex and subjective, investors are likely to perceive analysts' pre-tax earnings forecasts as a more credible (less noisy) performance benchmark than after-tax earnings forecasts. My first hypothesis is consistent with these arguments.

\section{H2: Investors use analysts' pre-tax earnings forecasts as an additional benchmark in evaluating firm performance.}

To test this prediction, I examine whether meeting pre-tax earnings benchmarks impacts investor reactions to a firm's after-tax earnings surprises.

2.4 Effect of Pre-Tax Earnings Forecasts on the Transparency of Tax-related Earnings Management

While my second hypothesis is focused on examining whether pre-tax forecasts convey information about firm performance and firm value, pre-tax forecasts are also expected to be informative in other ways. Specifically, pre-tax earnings forecasts should also increase the transparency of the tax expense account. Because studies have documented earnings management in the tax expense account, I examine whether pre-tax forecasts are informative about tax-related earnings management.

A large stream of prior literature examines earnings management (Dechow and Skinner (2000) provides one overview). While a large portion of the earnings management literature uses some aggregate measure of accruals, studies have also examined earnings management through specific income statement accounts. An 
example of this is the tax expense account. Dhaliwal et al. (2004) and Cook et al. (2008) provide evidence that managers use the tax account in a final effort to manage earnings. More specifically, their results suggest managers lower a firm's effective tax rate (ETR) in the fourth quarter in an attempt to meet/beat analysts' after-tax earnings targets.

While managers often have incentives to manage earnings, the effectiveness of earnings manipulation is less clear. Prior studies provide evidence firms receive a reward (increased market reactions) for meeting expectations but the reward is often discounted when investors perceive the earnings have been manipulated and are less persistent. Because of the complexity of the tax account, it remains unclear whether investors are able to identify manipulations of the tax account. Gleason and Mills (2008) examine whether investors discount earnings which result specifically from the management of the tax expense. By examining market reactions to earnings surprises, they provide evidence that investors significantly discount earnings which have been managed through decreasing the effective tax rate from the third to fourth quarter.

McInnis and Collins (2011) examine how cash flow forecasts affect the propensity of firms to meet/beat analysts' after-tax earnings forecasts. The authors argue that cash flow forecasts provide a forecast of operating accruals, increasing the cost of using accrual manipulations to manage earnings. I extend this argument by examining whether analysts' forecasts of a specific accrual, the tax expense account, influence the effectiveness of earnings management through the tax expense account. More specifically, I examine whether the market discounts tax-related earnings management more significantly when a firm receives pre-tax earnings forecast coverage. 
Assuming the availability of analysts' pre-tax earnings forecasts increases the transparency of the income tax expense account, my third hypothesis is stated as follows:

\section{H3: Tax-related earnings management is discounted more significantly}

\section{when firms receive pre-tax earnings forecast coverage.}

To test this hypothesis, I examine the market reactions for a set of firms meeting after-tax earnings benchmarks through tax-related earnings management. To identify whether additional forecasts increase the transparency of tax-related earnings management, I then examine whether this reaction is discounted to a greater degree when pre-tax forecast coverage is present.

\subsection{Effect of Pre-Tax Earnings Forecasts on Firm-level Tax Avoidance}

I next examine the impact of analysts' pre-tax earnings coverage on management behavior. To the extent I find results consistent with my first two hypotheses, managerial incentives to avoid taxes should be affected. More specifically, if pre-tax earnings are an important performance benchmark $(\mathrm{H} 2)$, managers will focus greater efforts on maximizing pre-tax earnings relative to decreasing the tax expense. In addition, if analyst coverage increases the transparency of the tax account (H3), investors are likely to react less favorably to aggressive tax strategies. I therefore examine whether initiations in pre-tax coverage by equity analysts impact a firm's level of tax avoidance. ${ }^{7}$

Several studies have examined incentives and consequences of tax avoidance (Hanlon and Heitzman 2010). While studies examine many aspects of tax avoidance, one question which remains is why many firms do not engage in more tax avoidance

\footnotetext{
${ }^{7}$ Consistent with Dyreng et al. (2008), I define tax avoidance as the ability of firms to pay a low amount of cash taxes relative to corporate earnings.
} 
(sometimes referred to as the 'undersheltering puzzle' (Weisbach 2002)). In their review, Hanlon and Heitzman (2010) discuss both benefits and costs that are associated with tax avoidance. One of the costs of tax avoidance is additional scrutiny, both from regulators as well as investors. As pre-tax earnings forecasts bring additional transparency and scrutiny to the tax expense account, these forecasts are likely to impact management's incentives to avoid taxes. More specifically, if more detailed forecasts increase scrutiny around the tax expense account, the costs of tax avoidance will increase. I regress changes in tax avoidance on initiations in analysts' pre-tax earnings forecast coverage. Assuming analyst coverage is associated with increased transparency and scrutiny, I arrive at my final hypothesis.

\section{H4: Initiations in analysts' pre-tax earnings coverage are negatively} associated with changes in tax avoidance. 


\section{RESEARCH DESIGN}

To test my first hypothesis regarding the determinants of pre-tax earnings forecasts, I identify specific firm-level tax characteristics which are likely to be associated with the level of interest in the income tax expense by investors. DeFond and Hung (2003) examine several determinants of cash flow forecasts, including firm size, capital intensity, accruals, financial health, and the volatility of earnings. To ensure the determinants they identify are not determinants of all disaggregated forecasts, I begin by running a model similar to theirs. I then examine the impact of additional firm-level characteristics, primarily related to the tax expense account. Specifically, I regress pretax earnings coverage on firms size, growth (market-to-book), book-tax differences, the number of geographical segments, the level of ETR, the volatility of ETR, and the number of analysts following a given firm. Lastly, I combine both of these models to better understand which factors are most meaningful in predicting pre-tax earnings forecast coverage (Equation 1c).

$$
\begin{aligned}
& \text { Pre-Tax } \\
& \beta_{i, \mathrm{t}}=\beta_{0}+\beta_{1} * \text { Size }_{\mathrm{i}, \mathrm{t}}+\beta_{2} * \text { Capital Intensity } \\
& \beta_{\mathrm{i}, \mathrm{t}}+ \\
& \beta_{6} * \text { Accruals }_{\mathrm{i}, \mathrm{t}}+\beta_{4} * \text { AltmanZ }_{\mathrm{i}, \mathrm{t}}+\beta_{5} * \text { VolEarnings }_{\mathrm{i}, \mathrm{t}}+ \\
& \beta_{5} * \beta_{7} * \text { StdETR }_{\mathrm{i}, \mathrm{t}}+\beta_{6} * \text { NFollow }_{\mathrm{i}, \mathrm{t}}+\varepsilon
\end{aligned}
$$

Pre-Tax is an indicator variable equal to 1 for firm-years where at least one analyst provides pre-tax earnings forecast coverage; 0 otherwise. The variables from DeFond and Hung are defined in Table 1. I include the number of analysts issuing aftertax forecasts (NFollow) to ensure additional disaggregated coverage is not simply for firms with the largest analyst following. I also include the volatility of taxes (StdETR) as a proxy for uncertainty related to the tax expense account. I predict that when the income 
tax expense is more volatile, the likelihood of pre-tax earnings forecasts increases. I also include the level of the effective tax rate (ETR) as a control for tax aggressiveness and I predict that when the effective tax rate is low, investors have more interest in pre-tax performance. I include the number of geographical segments (Segments) as firms which operate in many jurisdictions have greater complexity in the tax expense account. Booktax differences (BTD) can arise from several sources, such as the differences between tax and financial reporting systems and tax planning strategies. As book-tax differences are informative about the persistence of earnings (Hanlon, 2005) and earnings management (Blaylock et al., 2012), investors are likely to demand more tax-related information when book-tax differences are large. Lastly, I include growth (MTB) as the tax expense of companies is affected by the life cycle of the firm (Drake, 2012). Consistent with the demand hypothesis (H1), I predict that investors demand pre-tax earnings forecast coverage for firm-years with high growth, high book-tax differences, a large number of geographical segments, low effective tax rates, high volatility of taxes, and higher analyst following.

To test my second hypothesis, I use two main tests. First, I perform univariate analyses on cumulative abnormal returns during a 3-day window $(-1,+1)$ around earnings announcement dates. I partition the observations based on whether 1) the firm met/beat the after-tax (EPS) earnings forecast in a given year (Meet EPS/Miss EPS) and 2) the firm met/beat the pre-tax (PRE) forecast in a given year (Meet PRE/Miss PRE). I then examine whether there are significant differences between the 3-day CARs in each of the four quadrants. Prior research has provided evidence that firms are rewarded when 
meeting after-tax earnings forecasts. This study seeks to provide evidence that, conditional upon whether a firm meets/beats its after-tax earnings benchmarks, the market reaction to a firm's earnings is significantly more positive when a firm's pre-tax earnings benchmark is also attained.

Second, I examine my first hypothesis in a multivariate setting. I adapt a regression model from Rees and Sivaramakrishnan (2007) and Bartov et al. (2002).

$$
\begin{aligned}
& \mathrm{CAR}_{\mathrm{i}, \mathrm{t}}=\beta_{0}+\beta_{1} * \text { DShortBoth }_{\mathrm{i}, \mathrm{t}}+\beta_{2} * \text { DShortE }_{\mathrm{i}, \mathrm{t}}+ \\
& \beta_{3} * \text { DShortP }_{\mathrm{i}, \mathrm{t}}+\beta_{4} * \text { efe }_{\mathrm{i}, \mathrm{t}}+\beta_{5} *\left(\text { efe }^{*} \text { DShortBoth }\right)_{\mathrm{i}, \mathrm{t}}+ \\
& \beta_{6} *\left(\text { efe }^{*} \text { DShortE }\right)_{\mathrm{i}, \mathrm{t}}+\beta_{7} *(\text { efe } * \text { DShortP })_{\mathrm{i}, \mathrm{t}}+\beta_{8} * \text { prefe }_{\mathrm{i}, \mathrm{t}}+\varepsilon
\end{aligned}
$$

The dependent variable in Equation 2b is a firm's 3-day cumulative marketadjusted abnormal return around the date of earnings announcements in my analysis. The variable DShortE (DShortP) is equal to one if the after-tax (pre-tax) earnings surprise, but not the pre-tax (after-tax) surprise, is negative and zero otherwise. The variable DShortBoth is equal to one if both after-tax and pre-tax earnings surprises are negative and zero otherwise. These dummy variables are used to capture the incremental effects of meeting each benchmark on market reactions. As a result, the intercept $\left(\beta_{0}\right)$ captures the market reaction to firms that meet both their pre-tax and after-tax earnings benchmarks. I anticipate a positive coefficient on $\beta_{0}$ and negative coefficients on $\beta_{1}, \beta_{2}$, and $\beta_{3}$.

The after-tax earnings forecast error variable (efe) is the actual earnings less the median analyst forecast, scaled by stock price. The pre-tax forecast error (prefe) is equal to actual pre-tax earnings less the median pre-tax analyst forecast, scaled by stock price. Because analyst forecasts are important benchmarks to investors, I expect $\beta_{4}$ and $\beta_{8}$ to be 
positive. The other variables are interactions between the forecast error variables and the indicators for meeting (missing) forecasted benchmarks. These interactions illustrate how pre-tax performance affects the earnings response coefficient $\left(\beta_{4}\right)$, after controlling for after-tax earnings.

Hypothesis 2 predicts that $\beta_{1}, \beta_{2}$, and $\beta_{3}$ are all negative and the absolute value of $\beta_{1}$ is greater than $\beta_{2}$ and $\beta_{3}$. If the absolute value of $\beta_{1}$ is greater than $\beta_{2}$ and $\beta_{3}$ the results would suggest the market reward (penalty) is greater when both signals are consistent, indicating both signals are informative. To examine the relative weight placed on pre-tax and after-tax earnings, I compare $\beta_{2}$ and $\beta_{3}$. If aggregate earnings are weighed more heavily, I expect $\beta_{2}>\beta_{3}$.

To test my third hypothesis, I extend the findings of Gleason and Mills (2008) in my sample period. Therefore, I use their model (Equation 3a) to examine market reactions to earnings management through the tax expense account. Because their study examined a sample from 1995-2004, I first replicate this model for the sample of 20022011 to ensure their results hold in this later period. I then partition my sample and examine the results of this model for observations with and without pre-tax forecast coverage.

$$
\begin{aligned}
& \text { SA_CAR }_{\mathrm{i}, \mathrm{t}}=\beta_{0}+\beta_{1} * \text { Beat w/ tax } \\
& \beta_{\mathrm{i}, \mathrm{t}}+\beta_{2} * \mathrm{AFE}_{\mathrm{i}, \mathrm{t}}+ \\
& \beta_{3} * \text { Persistence }_{\mathrm{i}, \mathrm{t}}+\beta_{4} * \text { Beat w }_{\text {Tax }} * \text { Persistence }_{\mathrm{i}, \mathrm{t}}+ \\
& \beta_{5} * \mathrm{BM}_{\mathrm{i}, \mathrm{t}}+\beta_{6} * \text { Size }_{\mathrm{i}, \mathrm{t}}+\beta_{7} * \text { Momentum }_{\mathrm{i}, \mathrm{t}}+\varepsilon_{\mathrm{i}, \mathrm{t}}
\end{aligned}
$$

I then expand the initial model to examine whether the market discounts managed earnings more or less when pre-tax coverage exists on the entire sample (Equation $2 b$ ). 
SA_CAR ${ }_{i, t}=\beta_{0}+\beta_{1} * \operatorname{Pre}_{i, t}+\beta_{2} *$ Beat $w / \operatorname{tax}_{i, t}+$ $\beta_{3} *$ Beat $\mathrm{w} /$ tax $^{*}$ Pre $_{\mathrm{i}, \mathrm{t}}+\beta_{4} * \mathrm{AFE}_{\mathrm{i}, \mathrm{t}}+\beta_{5} *$ Persistence $_{\mathrm{i}, \mathrm{t}}+$

(Equation 3b)

$\beta_{6} *$ Beat w/ Tax $*$ Persistence $_{\mathrm{i}, \mathrm{t}}+\beta_{7} * \mathrm{BM}_{\mathrm{i}, \mathrm{t}}+\beta_{8} *$ Size $_{\mathrm{i}, \mathrm{t}}+\beta_{9} *$ Momentum $_{\mathrm{i}, \mathrm{t}}+\varepsilon_{\mathrm{i}, \mathrm{t}}$

The dependent variable, SA_CAR, is the five-day, size-adjusted, cumulative return for the firm centered on the earnings announcement date $(-2,+2)$. AFE refers to the forecast error, scaled by fiscal year-end stock price. Forecast errors are computed as actual earnings as reported by $\mathrm{I} / \mathrm{B} / \mathrm{E} / \mathrm{S}$ less the consensus forecast at the time of the earnings announcement.

The variable of interest (Beat w/ tax) is based on differences between third quarter estimated effective tax rates and actual, end-of-year, effective tax rates. The third quarter estimated effective tax rate (ETRq3) is the accumulated tax expense from the first three quarters divided by the accumulated pre-tax income from the same quarters. I then compute earnings per share based on the third quarter estimate of the effective tax rate (Earnings_ETRq3) as well as earnings per share based on the year-end effective tax rate (actual EPS). Earnings_ETRq3 = [annual pre-tax income $*(1-E T R q 3)] /$ number of common shares outstanding. Beat $\mathrm{w} /$ tax is an indicator variable equal to one if a firm met its after-tax earnings benchmark (if actual EPS >= Forecast) but would have missed the benchmark if the third quarter estimated effective tax rate was used (Earnings_ETRq3 $<$ Forecast), zero otherwise.

To measure the firm-specific prior persistence of fourth-quarter changes in the ETR, I utilize Schmidt's (2006) model which estimates the persistence of changes in the tax component of earnings (TCC) between year $t$ and year $t+1$. This model estimates the 
relation between tax change and non-tax change components of earnings and next year's earnings. ${ }^{8}$

All tax component variables are scaled by average total assets. I estimate firmyear persistence $\left(\beta_{2}\right)$ for each year using the previous eight years' observations. A minimum of five observations are required for each firm-year estimate.

I also include book-to-market ratio (BM), the natural log of total assets (Size), and cumulative size-adjusted returns for the six months preceding the earnings announcement (Momentum). These three controls are commonly used in finance and accounting capital market studies (e.g., Fama and French 1992, Gleason and Lee 2003).

To test my final hypothesis, I examine how initiations in pre-tax earnings forecast coverage are associated with changes in tax avoidance (Equation 4). While many proxies for tax avoidance are available, I initially utilize a three year measure of a firms cash effective tax rate (CETR), consistent with Dyreng et al. (2008). I use this three year measure because I expect additional attention on the tax account to impact tax avoidance over a longer period. More specifically, I expect to see long-term changes in tax avoidance rather than temporary changes. This measure of tax avoidance also follows the methodology used in Brown and Drake (2012) to examine changes in tax avoidance. The model used to test how initiations in analysts' pre-tax earnings coverage are associated with changes in tax avoidance is provided below.

\footnotetext{
${ }^{8}$ I regress Earn_TA $\mathrm{i}_{\mathrm{i}, t+1}=\beta_{0}+\beta_{1} *$ Earnings_ETRq3_TA $\mathrm{A}_{\mathrm{i}, \mathrm{t}}+\beta_{2} * \mathrm{TCC}_{-} \mathrm{TA} \mathrm{A}_{\mathrm{i}, \mathrm{t}}+\varepsilon_{\mathrm{i}, \mathrm{t}+1}$ where Earn_TA $=\mathrm{PTE} *$ (1-ETR) and Earnings_ETRq3 $=$ [annual pre-tax income $*(1$-ETRq3) $] /$ csho and TCC_TA $=$ PTE $*($ ETRq3-ETR). Firm-specific prior persistence $(\beta 2)$ is generated using observations from the previous eight years. I require a minimum of five observations per firm-year estimate. I winsorize Persistence at the 1 st and $99^{\text {th }}$ percentile.
} 
$\Delta \mathrm{CETR}_{\mathrm{i}, \mathrm{p}}=\beta_{0}+\beta_{1} * \mathrm{CETR}+\beta_{2} * \Delta \mathrm{PRE}_{\mathrm{i}, \mathrm{p}}+\beta_{3} * \Delta \mathrm{Size}_{\mathrm{i}, \mathrm{p}}+\quad$ (Equation 4)
$\beta_{4} * \Delta \mathrm{ROA}_{\mathrm{i}, \mathrm{p}}+\beta_{5} * \Delta \mathrm{LEV}_{\mathrm{i}, \mathrm{p}}+\beta_{6} * \Delta \mathrm{PPE}_{\mathrm{i}, \mathrm{p}}+\beta_{7} * \Delta \mathrm{Int}_{\mathrm{i}, \mathrm{p}}+\beta_{8} * \Delta$ For $_{\mathrm{i}, \mathrm{p}}+\varepsilon_{\mathrm{i}, \mathrm{p}}$

My dependent variable is a change in the three-year average cash ETR. More specifically, it is the difference in the average cash ETR in the three years beginning with year $t$ less the average cash ETR for the three years ending in year $\mathrm{t}-1$. All of the independent variables in the model are also changes in three-year average values. I also perform my analyses with a three-year GAAP ETR measure of tax avoidance (ETR) to ensure my results are not proxy-specific.

I first control for firm size, measured as the log of total assets. On one hand, Hoopes et al. (2012) find that IRS enforcement, which is positively correlated with firm size, is associated with lower levels of tax avoidance. As IRS enforcement represents increased scrutiny, other forms of additional scrutiny or monitoring should also result in less tax avoidance. However, larger firms often have more resources for tax planning, enhancing their ability to use more advanced tax strategies (Hanlon et al. 2005).

I also control for leverage (LEV) as Dyreng et al. (2008) finds leverage is associated with ETRs. To control for a firm's asset mix, I include both property, plant, and equipment (PPE) as well as intangible assets (INTANG). Prior research indicates firms with greater PPE have lower effective tax rates (Gupta and Newberry 1997). In addition, Hanlon et al. (2005) provide evidence that intangible assets are associated with greater tax planning opportunities.

I also include controls for both profitability (ROA) as well as an indicator variable capturing net operating losses (NOL). Firms with losses, or low profitability, are likely to have lower effective tax rates. In addition, I control for firms which have foreign 
income (FOR) as these firms often face lower effective tax rates due to their multijurisdictional presence.

I hypothesize that increases in pre-tax coverage are associated with decreases in tax avoidance, as evidenced by increases in a firm's cash effective tax rate. Therefore, my hypothesis predicts $\beta_{2}>0$. 


\section{DATA AND RESULTS}

I obtain all necessary data from I/B/E/S, CRSP, and Compustat. I use I/B/E/S data from 2002-2011 as there are virtually no pre-tax earnings forecasts prior to 2002. I restrict my sample to firms which have active pre-tax and after-tax earnings forecasts. Similar to Givoly et al. (2009), I define 'active' coverage as having at least one forecast from both the first and second half of the fiscal year. I attempt to limit my sample to active, recurring forecasts in an attempt to ensure analysts are actively following a firm.

Figure 1 displays evidence of the increasing pre-tax earnings coverage by analysts over the past decade. More specifically, less than $10 \%$ of firms receiving active after-tax forecasts also received active pre-tax earnings forecasts from at least one analyst in 2002. By 2011 , over $68 \%$ of firms receiving active after-tax forecasts also received active pretax earnings forecasts from at least one analyst.

\subsection{Results on the Determinants of Pre-Tax Earnings Forecast Coverage}

In Table 1, I examine the determinants of pre-tax earnings forecasts. Panel A provides descriptive statistics which illustrate the significant differences between firmyears observations with available pre-tax forecasts and observations without pre-tax forecasts. These differences highlight the importance of controlling for self-selection in later tests. Panel B presents multivariate results. Column 1 presents the results from a model originally used by DeFond and Hung (2003) in examining the determinants of cash flow forecasts. In column 2, I present results based on firm-level tax characteristics. In column 3, I present the full model incorporating column 1 and column 2. My results suggest the determinants identified by DeFond and Hung (2003) are not determinants of 
all non-EPS coverage. More specifically, when tax-related attributes are added to the model, the R-squared increases from 0.0317 (column 1) to 0.1359 (column 3). These results suggest firm-level tax characteristics are important factors in understanding when analysts and brokerages decide to issue additional pre-tax earnings forecasts.

I focus primarily on the firm-level tax characteristics in the analyses. In both columns 2 and 3, I find book-tax differences (BTD) and the volatility of taxes (StdETR) are positively and significantly associated with the issuance of pre-tax forecasts. These results are consistent with investor demand for additional information increasing when the complexity of the tax account is high. The number of geographical segments (Segments) is positive but significant only in column 2. The level of the effective tax rate (ETR) is negative and significant, consistent with investors demanding additional information when more aggressive tax strategies are employed. Lastly, I find that firms with greater analyst following (NFollow) have a higher likelihood of receiving publicly available pre-tax forecasts.

In Table 2, I display descriptive statistics about pre-tax earnings forecasts. Panel A provides additional time trend statistics. Consistent with Figure 1, I highlight significant increases in pre-tax coverage over time. More specifically, fewer than 2,000 analysts issued pre-tax earnings forecast coverage for at least one firm in 2002 while in 2011, 21,889 analysts issued pre-tax earnings forecast coverage for at least one firm. In addition, analysts provide more active pre-tax earnings forecasts as well. In 2002, analysts who provide pre-tax forecasts issued an average of 3.7 pre-tax forecasts for each firm-year but by 2011 analysts provided over 5.5 forecasts per firm-year. 
As discussed earlier, the dissemination of both pre-tax and after-tax earnings forecasts provides an implicit forecast of a firm's effective tax rate. Panel B provides basic descriptive statistics for this implied forecast. While not a significant focus of this study, analysts' mean effective tax rate forecast is $35 \%$. While the mean is close to the statutory rate of $35 \%$, it is important to note that there is significant variation in the forecasted effective tax rates. Even within a given analyst-firm-year observation, forecasted effective tax rates can vary significantly. ${ }^{9}$ Lastly, Panel C provides descriptive statistics by industry, using Fama-French 17 industry classifications.

\subsection{Results on Investor Use of Pre-Tax Earnings Forecasts}

To test whether investors use pre-tax earnings forecasts in evaluating firm performance (Hypothesis 2), I utilize both univariate and multivariate analyses. These results are provided in Table 3. Panel A provides descriptive statistics regarding the sample for these tests. Almost $45 \%$ of the firms in this sample met both their pre-tax and after-tax earnings forecasts. In addition, $28 \%$ of the firm-year observations missed both their pre-tax and after-tax earnings forecasts. While it is expected that firms' pre-tax and after-tax signals would largely be consistent, it is interesting to note that over $25 \%$ of the firm-year observations have mixed pre-tax and after-tax signals. The fact that pre-tax and after-tax signals are inconsistent for a significant portion of the sample increases the likelihood investors use both signals to evaluate performance.

\section{[INSERT TABLE 3 - PANEL A \& B]}

\footnotetext{
${ }^{9}$ For example, during 2008 one analyst of AmTech Systems provided an initial forecasted effective tax rate of $35 \%$. During the year the same analyst's forecasted effective tax rate decreased down to a low of $23 \%$ before ending the year at $36 \%$.
} 
Panel B of Table 3 reports correlations. As expected, Ab_ret is positively correlated with firms which meet both forecast targets (ShortNeither) and Ab_ret is negatively correlated with firms which miss both forecast targets (ShortBoth). However, Ab_ret is negatively correlated with firm-year observations which meet pre-tax targets but miss after-tax targets (ShortEarn), while Ab_ret is positively (but insignificantly) correlated with observations which miss pre-tax forecasts but meet after-tax forecasts. Although I test this more explicitly in subsequent multivariate analyses, the correlations suggest the investors weigh after-tax performance more heavily than pre-tax performance.

In Panel C of Table 3, I examine 3-day cumulative abnormal returns based on whether pre-tax forecasts as well as after-tax forecasts were met in a given firm-year. By examining abnormal returns in this $2 \times 2$ table, I provide initial evidence regarding the importance of pre-tax forecasts. Panel C suggests, similar to prior studies, firms that meet after-tax earnings targets are rewarded while firms that miss after-tax earnings targets are penalized.

Panel C also provides evidence of how returns vary based on whether or not pretax earnings benchmarks were met. I find significantly positive abnormal returns when a firm meets both its pre-tax and after-tax forecasts. When firms meet after-tax earnings forecasts but miss pre-tax earnings forecasts, the market reward continues to be positive but is significantly reduced. Conditional upon meeting after-tax earnings forecasts, I find significant differences between the market reward for firm-year observations where the pre-tax earnings forecast is met compared with observations where pre-tax forecasts are 
not met $(\mathrm{t}-\mathrm{stat}=13.03, \mathrm{p}$-value $<0.01)$. Likewise, when I examine observations where a firm misses both pre- and after-tax earnings forecasts, I find significantly negative abnormal returns. When I examine cases where firms miss after-tax earnings forecasts but meet pre-tax earnings forecasts, firms continue to receive negative abnormal returns but these returns are significantly less negative when compared to observations which miss both benchmarks $(\mathrm{t}-\mathrm{stat}=4.70, \mathrm{p}$-value $<0.01)$.

\section{[INSERT TABLE 3 - PANEL C \& D]}

The upper-right quadrant in Panel $\mathrm{C}$ is positive while the lower-left quadrant is negative. These results, while not surprising, suggest the market places greater weight on after-tax earnings, relative to pre-tax earnings. These results are consistent with the correlations in Panel B. However, the results from Table 3 suggest that the market does take into account whether or not pre-tax earnings forecasts are met. As this is a univariate test, I attempt to corroborate these findings with additional multivariate analyses.

Panel D of Table 3 contains multivariate results from models adapted from Rees and Sivaramakrishnan (2007). First, I use a simplified model in which I examine how after-tax forecast errors (efe), as well as pre-tax forecast errors (prefe), impact 3-day abnormal returns around earnings announcement dates. More specifically, I evaluate the following regression.

$$
\mathrm{CAR}_{\mathrm{i}, \mathrm{t}}=\beta_{0}+\beta_{4} * \mathrm{efe}_{\mathrm{i}, \mathrm{t}}+\beta_{8} * \text { prefe }_{\mathrm{i}, \mathrm{t}}+\varepsilon \quad \text { (Equation 2a) }
$$

Consistent with prior studies, Panel D of Table 2 suggests the earnings response coefficient $\left(\beta_{4}\right)$ is positive and significantly different from zero. In addition, $\beta_{8}$ is positive 
and significant, suggesting pre-tax earnings surprises are associated with abnormal returns, incremental to after-tax earnings surprises. This model does not directly examine whether investors use analysts' pre-tax earnings forecasts as the benchmark for pre-tax earnings. To more directly test whether these forecasts are used in performance evaluation, I examine how multiple benchmarks impact market reactions (Equation 2b).

$$
\begin{aligned}
& \text { CAR }_{\mathrm{i}, \mathrm{t}}=\beta_{0}+\beta_{1} * \mathrm{DShortBoth}_{\mathrm{i}, \mathrm{t}}+\beta_{2} * \mathrm{DShortE}_{\mathrm{i}, \mathrm{t}}+ \\
& \beta_{3} * \mathrm{DShortP}_{\mathrm{i}, \mathrm{t}}+\beta_{4} * \text { efe }_{\mathrm{i}, \mathrm{t}}+\beta_{5} *\left(\text { efe }^{*} \mathrm{DShortBoth}\right)_{\mathrm{i}, \mathrm{t}}+ \\
& \beta_{6} *\left(\text { efe }^{*} \mathrm{DShortE}\right)_{\mathrm{i}, \mathrm{t}}+\beta_{7} *(\text { efe } * \text { DShortP })_{\mathrm{i}, \mathrm{t}}+\beta_{8} * \text { prefe }_{\mathrm{i}, \mathrm{t}}+\varepsilon
\end{aligned}
$$

In Equation $2 \mathrm{~b}, \beta_{0}$ is the intercept which represents the market reward to meeting both pre- and after-tax earnings forecasts. $\beta_{0}+\beta_{1}$ represents the market penalty when both pre- and after-tax forecasts are not met. $\beta_{0}+\beta_{2}\left(\beta_{0}+\beta_{3}\right)$ indicate the market reaction when the after-tax (pre-tax) earnings forecast is not met but the pre-tax (aftertax) forecast is met. Hypothesis 1 predicts that market rewards to meeting after-tax earnings will be diminished if pre-tax earnings benchmarks are not attained. Likewise, market penalties to missing after-tax earnings are expected to be less severe if pre-tax earnings benchmarks are met.

As predicted, I find $\beta_{0}$ is positive and significant $(\mathrm{t}-\mathrm{stat}=21.55)$ consistent with the market rewarding firms that meet both their pre- and after-tax earnings forecasts. In addition, $\beta_{1}, \beta_{2}$, and $\beta_{3}$ are all negative and significant, consistent with the market penalizing firms for missing pre- and after-tax earnings benchmarks. The absolute value of $\beta_{1}$ is greater than both $\beta_{2}$ and $\beta_{3}$, indicating the market penalty is most severe when both benchmarks are missed. Lastly, it is important to notice the difference between $\beta_{2}$ and $\beta_{3}$. I find $\beta_{2}$ is significantly more negative than $\beta_{3}$, indicating that the market places 
greater weight on the after-tax earnings benchmark $(\mathrm{t}$-stat $=-6.18$, $\mathrm{p}$-value $<.01)$.

Overall, the results from Table 3 provide evidence consistent with my first hypothesis; that is, pre-tax earnings forecasts are used by investors in evaluating firm performance.

In column 2 of Panel $D$, the earnings response coefficient $\left(\beta_{4}\right)$ is positive and significant, while the coefficient on efe*DShortBoth $\left(\beta_{5}\right)$ is negative and significant. This result suggests the earnings response coefficient is significantly attenuated when firms miss both pre-tax and after-tax expectations. Likewise, the coefficient on efe*DShortE $\left(\beta_{6}\right)$ is negative and significant, suggesting the ERC is also attenuated when only the earnings expectations are missed. However, efe*DShortP $\left(\beta_{7}\right)$ is negative but insignificant, suggesting the ERC is not affected when a firm fails to meet pre-tax earnings expectations. Lastly, while PFE is positive and significant in column (1), it is insignificant in column (2). These results suggest that investors react more to the signal of meeting/missing pre-tax forecasts than valuation implications from the magnitude of the pre-tax earnings forecast error. ${ }^{10}$

4.3 Results on the Effect of Pre-Tax Earnings Forecasts on the Transparency of Taxrelated Earnings Management

To test my third hypothesis, I follow the methodology of Dhaliwal et al. (2004), Cook et al. (2008), and Gleason and Mills (2008) in identifying the firms that utilized the tax account to manage earnings. Because quarterly estimates of the effective tax rate are intended to be estimates of the final annual effective tax rate, this methodology focuses

\footnotetext{
${ }^{10}$ In untabulated results, I also include the revenue forecast error (revfe), similar to Rees and Sivaramakrishnan (2007). With this additional disaggregated signal, my results continue to be qualitatively and quantitatively consistent, alleviating the concern that pre-tax forecast errors may simply be associated with revenue forecast errors.
} 
on fourth-quarter changes in the effective tax rate. More specifically, a firm is identified as managing earnings through the tax account (Beat w/ Tax $=1$ ) if a firm would have missed its after-tax earnings forecast using the third quarter effective tax rate but the firm did meet the earnings forecast with a lower, final effective tax rate. If a firm would have met its after-tax earnings with either its third quarter, or final, effective tax rates, a firm is identified as not managing earnings through the tax account (Beat w/ Tax $=0)$. I examine all firm-year observations between 2002-2011 and, based on the methodology previously mentioned, code Beat w/ Tax. I then merge this sample with $\mathrm{I} / \mathrm{B} / \mathrm{E} / \mathrm{S}$ and require all firm-year observations to have after-tax (EPS) forecast coverage.

Descriptive statistics are provided in Panel A of Table 4. Because of the additional data requirements for this model, particularly the requirement to have a measure of persistence, the sample is much smaller than in Table 3. Event returns (SA_CAR) and momentum are both significantly higher for firms with pre-tax earnings forecast coverage. Panel B of Table 4 provides both Pearson and Spearman correlations. Consistent with the results in Panel A, I find firm-year observations with pre-tax coverage are correlated with higher event-window returns. I fail to find significant correlations between Pre and Beat w/ tax, suggesting the frequency of tax-related earnings management is not significantly different based on pre-tax coverage

$$
\text { [INSERT TABLE } 4 \text { - PANEL A \& B] }
$$

The multivariate analyses testing my second hypothesis are presented in Panel C. In column 1 of Panel C, I replicate the model from Gleason and Mills (2008) for my sample period of 2002-2011. The main variable of interest, Beat w/ Tax, is negative and 
significant although it is only significant at the $10 \%$ level. AFE continues to be positive and significant and Momentum continues to be negative and significant. The interaction of Beat w/ Tax * Persistence is positive and significant, while this interaction was insignificant for Gleason and Mills (2008) sample period of 1995-2004.

[INSERT TABLE 4 HERE - PANEL C]

In columns (2) and (3) I partition my sample based on whether or not a firm received analyst pre-tax earnings forecast coverage in a given year. I then run the same model on firms without pre-tax coverage (column 2) as well as on firms with pre-tax coverage (column 3). In column 2, Beat w/ Tax is negative but insignificant. These results are not consistent with the market significantly discounting 'last chance' (taxrelated) earnings management. However, for firm-years with pre-tax earnings forecast coverage (column 3), Beat w/ Tax is negative and significant. The differences between columns 2 and 3 suggest that 'last chance' earnings management is discounted more severely when analysts are providing explicit pre-tax earnings forecasts. These results are consistent with analysts increasing the transparency of the tax expense account. Consistent with McInnis and Collins (2011), my results suggest that additional non-EPS forecasts can increase the transparency of certain earnings management strategies. Lastly, in column 4, I include the entire sample with an interaction between Beat w/ Tax and the presence of pre-tax forecasts (Pre) (Equation 3b). While this interaction (Beat* Pre) is insignificant by itself, the joint hypothesis of $\beta_{3}+\beta_{4}$ shows that for firms with pretax coverage, tax-related earnings management is significantly discounted $(\mathrm{t}$-stat $=-2.06$, p-value $<0.05)$ 
Overall, my results are consistent with the market discounting earnings which are managed through the tax expense. More importantly, my results suggest the market is better able to identify this earnings management, and subsequently discount those earnings, when analysts' pre-tax earnings forecasts are available. These results suggest an additional benefit to investors when analysts provide more detailed forecasts; increasing the transparency of earnings management through individual accounts. In untabulated results, I also employ an endogenous switching regression model to account for selection biases as pre-tax coverage is not random. These results are qualitatively and quantitatively similar to the results reported in Table 4.

4.4 Results on the Effect of Pre-Tax Earnings Forecasts on Firm-level Tax Avoidance

To test my fourth and final hypothesis, I examine how the initiation of analysts' pre-tax earnings coverage is associated with changes in firm-level tax avoidance.

Following Dyreng et al. (2008), my primary measure of tax avoidance is the firm's cash ETR (CETR). As discussed by Dyreng et al. (2008), one-year tax avoidance measures are often noisy. ${ }^{11}$ As a result, I use a three-year average cash ETR in calculating both tax avoidance measures. If additional scrutiny and transparency regarding income taxes results from analysts' tax-related forecasts, I predict initiations of tax-related forecasts are associated with decreases in tax avoidance. As mentioned previously, the base model I use is as follows:

$$
\begin{aligned}
& \Delta \mathrm{CETR}_{\mathrm{i}, \mathrm{p}}=\beta_{0}+\beta_{1} * \mathrm{CETR}+\beta_{2} * \Delta \mathrm{PRE}_{\mathrm{i}, \mathrm{p}}+\beta_{3} * \Delta \operatorname{Size}_{\mathrm{i}, \mathrm{p}}+\quad \text { (Equation 4) } \\
& \beta_{4} * \Delta \mathrm{ROA}_{\mathrm{i}, \mathrm{p}}+\beta_{5} * \Delta \mathrm{LEV}_{\mathrm{i}, \mathrm{p}}+\beta_{6} * \Delta \mathrm{PPE}_{\mathrm{i}, \mathrm{p}}+\beta_{7} * \Delta \mathrm{Int}_{\mathrm{i}, \mathrm{p}}+\beta_{8} * \Delta \mathrm{For}_{\mathrm{i}, \mathrm{p}}+\varepsilon_{\mathrm{i}, \mathrm{p}}
\end{aligned}
$$

\footnotetext{
${ }^{11}$ As discussed below, I do examine one year changes for robustness and find the results are quantitatively similar.
} 
I also use an alternative model using an alternative tax avoidance measure, GAAP ETR (ETR). In addition, while the base model looks at the initiation of analyst pre-tax coverage, I also examine whether the impact is more significant for initiations which are covered by a larger number of analysts. To examine this, I replace $\triangle \mathrm{PRE}$ (an indicator variable capturing a change in pre-tax coverage) with $\triangle \mathrm{nPRE}$ (a discrete variable capturing the number of analysts issuing pre-tax earnings forecasts after initiation).

The dependent variable in this Equation 4 is the change in a firm's three-year cash effective tax rate (CETR) from period $\mathrm{p}-1$ to period $\mathrm{p}$, where $\mathrm{p}-1$ captures the three year period ending the year prior to initial pre-tax earnings forecast coverage and $\mathrm{p}$ captures the three year period beginning with the first year of initial pre-tax coverage. All other change variables are also calculated as changes from period p-1 to period p. I include CETR as of time period p-1 as a control variable to address concerns of results being driven by mean reversion.

\section{[INSERT TABLE 5 - PANEL A \& B]}

Panel A of Table 5 contains descriptive statistics for this sample. The mean cash effective tax rate $(18.4 \%)$ is much lower than the mean GAAP effective tax rate $(27.2 \%)$. This difference illustrates the impact of temporary differences as the GAAP effective tax rate is only impacted by permanent differences while cash effective tax rates capture both temporary and permanent differences. Panel B of Table 5 provides correlations of the variables of interest.

Panel C of Table 5 provides multivariate results regarding the impact of analysts' tax-related forecasts on management incentives regarding the income tax expense 
account. In both specifications using cash ETR as a proxy for tax avoidance, the coefficient on $\triangle \mathrm{PRE}(\triangle \mathrm{nPRE})$ is positive and significant. This result is consistent with an increase in a firm's cash ETR, in line with a decrease in tax avoidance. Using GAAP ETR, I fail to find consistent results. More specifically, $\triangle \mathrm{nPRE}$ (column 3) is positive but only weakly significant (one-tailed p-value $=0.089$ ) and $\triangle \mathrm{PRE}$ (column 4) is positive but insignificant. The fact GAAP ETR does not load as significant may be a result of the lingering pressure to maximize after-tax earnings. Overall, I interpret these results as initial evidence that additional non-EPS forecasts impact management incentives regarding specific income statement accounts.

In untabulated results, I also employ a treatment effects regression model to address selection biases as pre-tax coverage is not random. These results are qualitatively and quantitatively similar to the results report in Table 5. Overall, my results provide initial evidence suggesting analyst coverage of pre-tax forecasts does impact management incentives regarding income taxes. In untabulated results, I examine one-year changes and also find similar results. This result is in line with other studies that indicate analysts' forecasts are seen as important benchmarks which impact managerial incentives (Kasznik and McNichols, 2002). 


\section{CONCLUSION}

This study examines how analysts' disaggregated income statement forecasts impact investors and managerial incentives. Prior literature has documented investors' attention to whether firms meet/beat analysts' aggregate, after-tax earnings (EPS) forecasts. I hypothesize that when additional income statement line-item forecasts, such as pre-tax earnings forecasts, are provided, investors also weigh these forecasts in evaluating firm performance. This expectation is, in part, due to the hypothesis that additional pre-tax forecasts are made available when investors demand additional information about the tax expense account. In addition, I predict tax-related forecasts increase the transparency of tax-related earnings management. Lastly, if investors use pre-tax earnings forecasts in evaluating firm performance and in understanding taxrelated earnings management, I examine whether pre-tax earnings coverage impacts managerial incentives regarding the pre-tax income and the tax expense account.

My results suggest that pre-tax forecasts are available when investors demand additional information and that investors use additional income statement line item forecasts in evaluating firm performance. More specifically, the rewards or consequences associated with a firm meeting or missing after-tax earnings forecasts are largely affected by whether or not the firm is able to meet its pre-tax earnings forecast. While this is consistent with prior literature examining sales forecasts, this study is the first to my knowledge that examines the information content of forecasts of a specific expense account. In addition, analyst coverage of pre-tax earnings, which also provide an implicit forecast of a firm's effective tax rate, does increase the transparency of tax- 
related earnings management. Lastly, consistent with the additional scrutiny on pre-tax earnings and the tax expense account, I find some evidence that initiations of pre-tax forecast coverage are associated with decreases in firm-level tax avoidance.

This study contributes to the growing literature on disaggregated, non-EPS forecasts. My results suggest additional forecasts are useful to investors and can impact managerial incentives. More specifically, pre-tax earnings forecasts appear to enhance the transparency of the tax expense account and its impact on a firm's overall performance. Future research is needed to examine other settings where pre-tax earnings forecasts may be useful as well as settings in which additional non-EPS forecasts are also useful. In addition, future research may examine multiple disaggregated forecasts to examine whether specific income statement line-item analyst forecasts are more or less accurate in an attempt to open the 'black box' of analysts' forecasting process. 


\section{APPENDIX A}

\section{FIGURES}

Figure 1 Percentage of Firms with Both Pre- and After-Tax Earnings

Forecast Coverage ...................................... 
Figure 1: Percentage of firms with both pre- and after-tax earnings forecast coverage

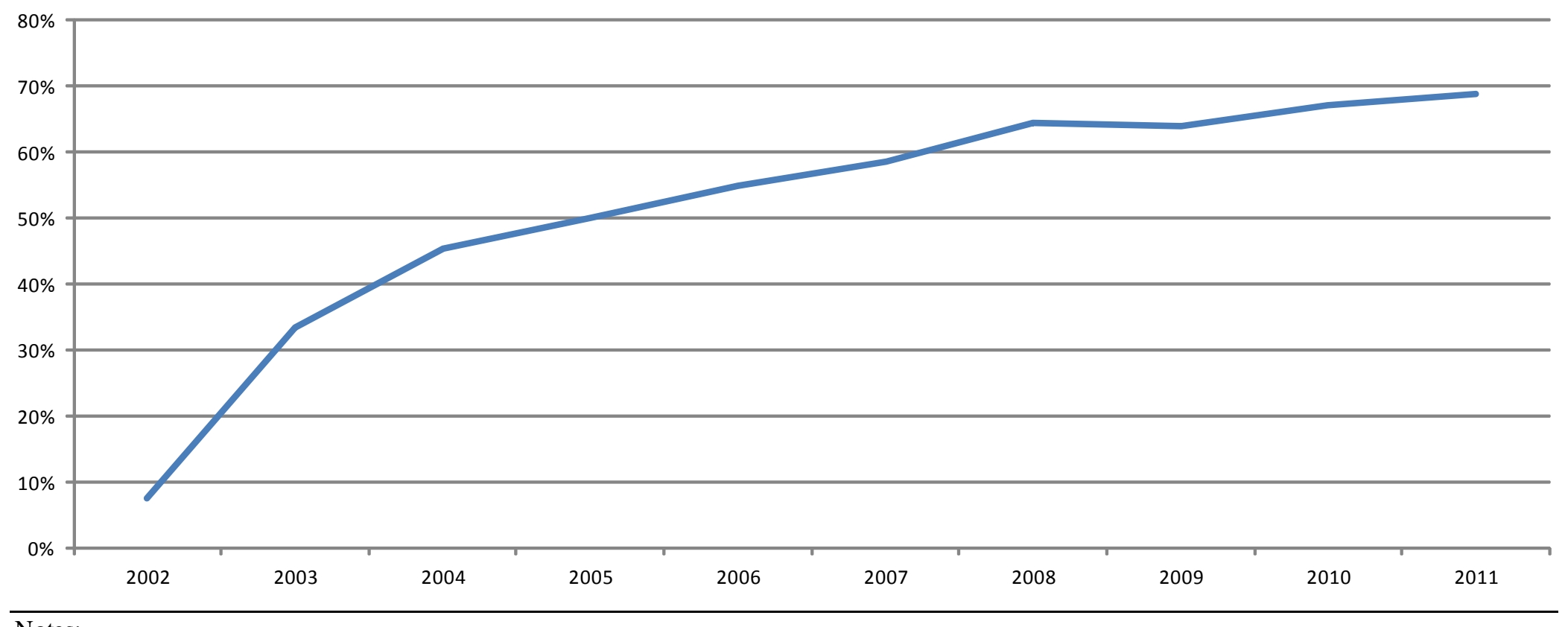

Notes:

Figure 1 displays the increasing prevalence of one-year ahead pre-tax earnings forecast coverage over the past decade. Specifically, coverage is obtained from I/B/E/S between 2002-2011. To be included in the sample, a firm must have at least one 'active' after-tax forecast, defined as having at least one analyst which issued forecasts in both the first half and second half of a firm's fiscal year. In addition, to be classified as having pre-tax coverage, a firm must receive 'active' (as defined above) pre-tax forecasts from at least one analyst in a given year. 


\section{APPENDIX B}

\section{TABLES}

Table 1 Determinants of the Issuance of Pre-tax Earnings Forecasts..... 48

Table 2 Descriptive Statistics of Pre-Tax Earnings Forecasts........... 50

Table 3 The Impact of Pre-Tax Earnings Forecasts on Firm Performance Evaluation........................................... 51

Table 4 The Impact of Analysts' Pre-Tax Coverage on the Transparency of Tax-Related Earnings Management.......................... 54

Table 5 The Impact of Analysts' Pre-Tax Coverage on Tax Avoidance... 56 
Table 1: Determinants of the Issuance of Pre-tax Earnings Forecasts

Panel A: Descriptive statistics

\begin{tabular}{cccccccc} 
& \multicolumn{3}{c}{ No Pre-tax Coverage } & & \multicolumn{3}{c}{ Pre-tax coverage } \\
\cline { 2 - 4 } \cline { 6 - 8 } Variable & $\underline{\text { Mean }}$ & $\underline{\text { Median }}$ & $\underline{\text { Std Dev }}$ & & $\underline{\text { Mean }}$ & $\underline{\text { Median }}$ & $\underline{\text { Std Dev }}$ \\
Size & 6.247 & 6.000 & 1.878 & & 6.8697 & 6.7256 & 1.7354 \\
Capital Intensity & 1.077 & 0.429 & 1.900 & & 0.9053 & 0.3670 & 1.7460 \\
Accruals & 0.099 & 0.061 & 0.129 & & 0.0885 & 0.0590 & 0.1062 \\
AltmanZ & 5.901 & 3.297 & 10.052 & & 5.0991 & 3.5560 & 6.4182 \\
StdEarnings & 0.119 & 0.046 & 0.232 & & 0.1051 & 0.0387 & 0.2278 \\
MTB & 2.564 & 1.835 & 3.776 & & 2.8934 & 2.1220 & 3.9312 \\
BTD & -0.029 & 0.007 & 0.221 & & 0.0003 & 0.0140 & 0.1871 \\
Segments & 2.874 & 2.000 & 2.172 & & 3.1818 & 3.0000 & 2.4022 \\
ETR & 0.224 & 0.258 & 0.210 & & 0.2409 & 0.2822 & 0.2016 \\
StdETR & 0.095 & 0.048 & 0.109 & & 0.1022 & 0.0569 & 0.1110 \\
Nfollow & 3.220 & 2.000 & 3.720 & & 7.3614 & 6.0000 & 5.9943
\end{tabular}

Table 1 reports descriptive statistics. Size equals the natural log of the market value of equity in millions. Capital Intensity equals the ratio of gross property, plant, and equipment scaled by sales revenue. Accruals equal the difference between net income before extraordianary items minus operating cash flows, scaled by total assets. AltmanZ is a measure of financial health, calculated as $1.2 *$ (Net working capital/Total assets $)+1.4 *$ (Retained Earnings/Total Assets)+3.3*(Earnings before interest and taxes/Total assets)+0.6*(Market Value of Equity/Book Value of Liabilities) $+1.0 *$ (Sales/Total assets). StdEarnings equals the standard deviation of earnings over the past five years. MTB equals market value of equity divided by book value of equity. BTD captures book-tax differences, calculated as the difference between book income and taxable income, scaled by average total assets. Book Income equals the difference between pre-tax income and minority interest. Taxable Income equals the difference between federal and foreign income taxes, scaled by the statutory tax rate, less changes in net operating losses. Segments equals the number of geographical segments within a firm. ETR is a firms effective tax rate, equal to total income taxes divided by pre-tax income. StdETR is the standard deviation of ETR over the past 3 years. Nfollow equals the number of analysts providing after-tax (EPS) forecasts in a given firm-year. 
Table 1: Determinants of Pre-Tax Earnings Forecast Coverage

Panel B: Multivariate analysis

Pre-Tax $_{i, t}=\beta_{0}+\beta_{1} *$ Size $_{i, t}+\beta_{2} *$ Capital Intenisty $_{i, t}+\beta_{3} *$ Accruals $_{i, t}+\beta_{4} *$ AltmanZ $_{i, t}+\beta_{5} *$ VolEarnings $_{i, t}+\varepsilon_{i, t}$

(Equation 1a)

$\operatorname{Pre}-T a x_{i, t}=\beta_{0}+\beta_{1} *$ Size $_{i, t}+\beta_{2} * M T B_{i, t}+\beta_{3} *$ BTD $_{i, t}+\beta_{4} *$ Segments $_{i, t}+\beta_{5} *$ ETR $_{i, t}+\beta_{6} * \operatorname{StdETR}_{i, t}+\beta_{7} *$

NFollow $_{i, t}+\varepsilon_{i, t}$

(Equation 1b)

Pre-Tax $_{i, t}=\beta_{0}+\beta_{1} *$ Size $_{i, t}+\beta_{2} *$ Capital Intenisty $_{i, t}+\beta_{3} *$ Accruals $_{i, t}+\beta_{4} *$ Altman $_{i, t}+\beta_{5} *$ VolEarnings $_{i}, t+\beta_{6}$

$*$ MTB $_{i, t}+\beta_{7} *$ BTD $_{i, t}+\beta_{8} *$ Segments $_{i, t}+\beta_{9} *$ ETR $_{i, t}+\beta_{10} * \operatorname{StdETR}_{i, t}+\beta_{11} *$ NFollow $_{i, t}+\varepsilon_{i, t} \quad$ (Equation 1c)

\begin{tabular}{|c|c|c|c|c|}
\hline Variable: & Prediction: & $\underline{1}$ & $\underline{2}$ & $\underline{3}$ \\
\hline \multirow[t]{2}{*}{ Constant } & & -0.2344 & 0.5276 & 0.905 \\
\hline & & 0.0396 & $<.0001$ & $<.0001$ \\
\hline \multirow[t]{2}{*}{ Size } & & 0.2363 & -0.1238 & -0.1101 \\
\hline & & $<.0001$ & $<.0001$ & $<.0001$ \\
\hline \multirow[t]{2}{*}{ Capital Intensity } & & -0.0554 & & -0.0769 \\
\hline & & $<.0001$ & & $<.0001$ \\
\hline \multirow[t]{2}{*}{ Accruals } & & 0.00909 & & -0.5673 \\
\hline & & 0.9581 & & 0.002 \\
\hline \multirow[t]{2}{*}{ AltmanZ } & & -0.017 & & -0.018 \\
\hline & & $<.0001$ & & $<.0001$ \\
\hline \multirow[t]{2}{*}{ VolEarnings } & & 0.057 & & 0.0609 \\
\hline & & 0.5272 & & 0.5145 \\
\hline \multirow[t]{2}{*}{ МТВ } & & & 0.00642 & 0.0053 \\
\hline & & & 0.1986 & 0.3795 \\
\hline \multirow[t]{2}{*}{ BTD } & + & & 0.7591 & 0.4073 \\
\hline & & & $<.0001$ & 0.0007 \\
\hline \multirow[t]{2}{*}{ Segments } & + & & 0.0304 & 0.0144 \\
\hline & & & 0.0008 & 0.1695 \\
\hline \multirow[t]{2}{*}{ ETR } & - & & -0.2346 & -0.7053 \\
\hline & & & 0.0101 & $<.0001$ \\
\hline \multirow[t]{2}{*}{ StdETR } & + & & 0.8146 & 0.9451 \\
\hline & & & $<.0001$ & $<.0001$ \\
\hline \multirow[t]{2}{*}{ NFollow } & + & & 0.2428 & 0.2373 \\
\hline & & & $<.0001$ & $<.0001$ \\
\hline Year FE & & $\mathrm{Y}$ & Y & $\mathrm{Y}$ \\
\hline Industry FE & & Y & Y & $\mathrm{Y}$ \\
\hline $\mathrm{N}$ & & 21141 & 26276 & 18825 \\
\hline $\mathrm{R}$-squared & & 0.0317 & 0.1393 & 0.1359 \\
\hline
\end{tabular}

\section{Notes:}

Panel B of Table 1 displays multivariate analysis of logistic models examining the determinants of the issuance of pre-tax forecasts.

Column 1 reports results based on Equation 1a. Column 2 reports results based on Equation 1b. Column 3 reports results based on Equation 1c. Size equals the natural log of the market value of equity in millions. Capital Intensity equals the ratio of gross property, plant, and equipment scaled by sales revenue. Accruals equal the difference between net income before extraordianary items minus operating cash flows, scaled by total assets. AltmanZ is a measure of financial health, calculated as $1.2 *$ (Net working capita/Total assets)+1.4*(Retained Earnings/Total Assets) $+3.3 *$ (Earnings before interest and taxes/Total assets) $+0.6 *($ Market Value of Equity/Book Value of Liabilities) $+1.0 *$ (Sales/Total assets). StdEarnings equals the standard deviation of earnings over the past five years. MTB equals market value of equity divided by book value of equity. BTD captures book-tax differences, calculated as the difference between book income and taxable income, scaled by average total assets. Book Income equals the difference between pre-tax income and minority interest. Taxable Income equals the difference between federal and foreign income taxes, scaled by the statutory tax rate, less changes in net operating losses. Segments equals the number of geographical segments within a firm. ETR is a firms effective tax rate, equal to total income taxes divided by pre-tax income. StdETR is the standard deviation of ETR over the past 3 years. Nfollow equals the number of analysts providing after-tax (EPS) forecasts in a given firm-year. 
TABLE 2: Descriptive statistics regarding pre-tax earnings forecast

Panel A: Time-trend statistics

\# of pre-tax forecasts

\# of individual analysts issuing pre-tax forecasts

\# of forecasts per analyst issuing pre-tax forecasts

\# of firms receiving pre-tax forecast coverage

\begin{tabular}{cccccccccc}
2002 & 2003 & 2004 & 2005 & 2006 & 2007 & 2008 & 2009 & 2010 & 2011 \\
\hline 7032 & 32018 & 54847 & 65394 & 77175 & 83994 & 96837 & 102373 & 114635 & 121029 \\
1884 & 6999 & 11107 & 13025 & 15109 & 16224 & 16981 & 18063 & 20630 & 21889 \\
3.732 & 4.575 & 4.938 & 5.021 & 5.108 & 5.177 & 5.703 & 5.668 & 5.557 & 5.529 \\
1031 & 2365 & 2968 & 3283 & 3479 & 3684 & 3653 & 3407 & 3516 & 3500 \\
& & & & & & & & &
\end{tabular}

Panel B: Implied forecasted effective tax rates

\begin{tabular}{ccc} 
Mean & Median & Std. Dev. \\
\hline & & \\
0.3502 & 0.3598 & 0.1376 \\
0.3406 & 0.3509 & 0.1387
\end{tabular}

Forecasted ETR

$\begin{array}{lll}0.3406 & 0.3509 & 0.1387\end{array}$

Panel C: Breakdown of pre-tax coverage by industry (Fama French 17 classification)

Retail Stores

Machinery and Business Equipment

Drugs, Soap, Tobacco

Oil and Petro Products

Transporation

Food

Textiles, Apparel \& Footware

Construction

Automobiles

Steel

Fabricated Products

Utilities

Chemicals

Financial Institutions

Mining and Minerals

Consumer Durables

Other

\begin{tabular}{ccc}
$(1)$ & $(2)$ & $(3)$ \\
W/ EPS Cov & W/ Pre Cov & $\%$ \\
\hline 2698 & 1665 & $61.71 \%$ \\
6242 & 3694 & $59.18 \%$ \\
2127 & 1257 & $59.10 \%$ \\
2184 & 1281 & $58.65 \%$ \\
1943 & 1126 & $57.95 \%$ \\
1120 & 632 & $56.43 \%$ \\
703 & 394 & $56.05 \%$ \\
1136 & 629 & $55.37 \%$ \\
660 & 359 & $54.39 \%$ \\
594 & 319 & $53.70 \%$ \\
299 & 156 & $52.17 \%$ \\
1492 & 773 & $51.81 \%$ \\
887 & 444 & $50.06 \%$ \\
9684 & 4739 & $48.94 \%$ \\
786 & 358 & $45.55 \%$ \\
832 & 378 & $45.43 \%$ \\
28838 & 12688 & $44.00 \%$
\end{tabular}

Notes:

Table 2 provides descriptive statistics about analysts' pre-tax earnings forecasts, as provided by I/B/E/S. These statistics are provided for analyst-firm-year observations with 'active' pre-tax earnings forecast coverage. Active coverage is defined as an analyst having issued pre-tax earnings forecasts in both the first half and second half of a firm's fiscal year. In Panel A, general trend statistics are provided. In Panel B, the implied effective tax rates resulting from the issuance of both pre-tax and after-tax forecasts are provided. In Panel C, I display industry statistics using Fama French 17 industry classification. I report the number of firm-years with active after-tax coverage (column 1), the number of firm-years with active pre-tax earnings coverage (column 2), and then the percent of firms with after-tax coverage also receiving pre-tax coverage (column 3). 
TABLE 3: The impact of pre-tax earnings forecasts on firm performance evaluation

Panel A: Descriptive statistics

\begin{tabular}{lccc} 
Variable & $\underline{\mathbf{N}}$ & $\underline{\text { Mean }}$ & $\underline{\text { Median }}$ \\
\hline Ab_ret & 21479 & 0.0022 & 0.0013 \\
EFE & 21479 & -0.0051 & 0.0004 \\
PreFE & 21350 & -0.0076 & 0.0001 \\
ShortEarn & 21479 & 0.0656 & 0.0000 \\
ShortPre & 21479 & 0.2036 & 0.0000 \\
ShortBoth & 21479 & 0.2814 & 0.0000 \\
ShortNeither & 21479 & 0.4493 & 0.0000
\end{tabular}

Panel B: Correlations

\begin{tabular}{lccccccc} 
& Ab_ret & EFE & PreFE & ShortEarn & ShortPre & ShortBoth & ShortNeither \\
\cline { 2 - 7 } Ab_ret & & $\mathbf{0 . 0 6 0 8}$ & $\mathbf{0 . 0 5 8 7}$ & $\mathbf{- 0 . 0 5 1 8}$ & 0.0071 & $\mathbf{- 0 . 2 0 8 1}$ & $\mathbf{0 . 2 0 8 1}$ \\
EFE & $\mathbf{0 . 2 5 7 1}$ & & $\mathbf{0 . 7 9 9 1}$ & -0.0111 & $\mathbf{0 . 0 6 0 2}$ & $\mathbf{- 0 . 1 9 6 0}$ & $\mathbf{0 . 1 3 4 0}$ \\
PreFE & $\mathbf{0 . 1 8 3 1}$ & $\mathbf{0 . 5 7 0 5}$ & & $\mathbf{0 . 0 6 9 5}$ & $\mathbf{0 . 0 3 4 0}$ & $\mathbf{0 . 2 0 9 2}$ & $\mathbf{0 . 1 8 1 8}$ \\
ShortEarn & $\mathbf{- 0 . 0 5 6 5}$ & $\mathbf{- 0 . 2 6 7 5}$ & $\mathbf{0 . 2 3 5 9}$ & & $\mathbf{- 0 . 1 3 4 0}$ & $\mathbf{- 0 . 1 6 5 9}$ & $\mathbf{- 0 . 2 3 9 4}$ \\
ShortPre & $\mathbf{0 . 0 1 2 8}$ & $\mathbf{0 . 1 8 6 4}$ & $\mathbf{- 0 . 3 6 7 7}$ & $\mathbf{- 0 . 1 3 4 0}$ & & $\mathbf{- 0 . 3 1 6 4}$ & $\mathbf{- 0 . 4 5 6 8}$ \\
ShortBoth & $\mathbf{- 0 . 2 1 9 9}$ & $\mathbf{- 0 . 7 2 3 3}$ & $\mathbf{- 0 . 6 3 0 5}$ & $\mathbf{- 0 . 1 6 5 9}$ & $\mathbf{- 0 . 3 1 6 4}$ & & $-\mathbf{0 . 5 6 5 3}$ \\
ShortNeither & $\mathbf{0 . 2 1 6 6}$ & $\mathbf{0 . 6 3 6 1}$ & $\mathbf{0 . 7 4 9 8}$ & $\mathbf{- 0 . 2 3 9 4}$ & $\mathbf{- 0 . 4 5 6 8}$ & $\mathbf{- 0 . 5 6 5 3}$ & \\
& & & & & & &
\end{tabular}

Notes:

Panel A of Table 3 displays descriptive statistics for firms receiving both pre-tax and after-tax earnings forecast coverage. I perform t-tests to determine whether abnormal returns around earnings announcement dates are different based on whether a firm met/missed its' pre-tax and/or after-tax earnings targets. Ab_ret is equal to a firm's 3-day (-1, +1 ) cumulative market-adjusted abnormal return. ShortBoth is an indicator variable equal to 1 if a firm misses both its' pre- and after-tax earnings forecasts; 0 otherwise. ShortEarn is an indicator variable equal to 1 if a firm ONLY misses its' after-tax earnings forecasts; 0 otherwise. ShortBoth is an indicator variable equal to 1 if a firm ONLY misses its' pretax earnings forecasts; 0 otherwise. EFE represents the after-tax earnings forecast error equal to actual after-tax earnings per share less the median analyst after-tax earnings per share forecast, scaled by end of year stock price. PFE represents the pre-tax earnings forecast error equal to actual pre-tax earnings per share less the median analyst pre-tax earnings per share forecast, scaled by end of year stock price. Panel B of Table 3 displays correlations. Pearson correlations are reported above the diagonal while Spearman correlations are reported below the diagonal. Bold numbers indicated correlations which are significant at the $10 \%$ level. 
TABLE 3: The impact of pre-tax earnings forecasts on firm performance evaluation

Panel C: 3-Day CARs around earnings announcement dates

\begin{tabular}{|c|c|c|c|c|}
\hline & \multirow[b]{2}{*}{ Meet Pre } & \multirow[b]{2}{*}{$\underline{\text { Miss Pre }}$} & \multicolumn{2}{|c|}{ Test of Differences } \\
\hline & & & $\underline{\mathrm{T} \text {-stat }}$ & $\mathrm{p}$-value \\
\hline Meet EPS & 0.0197 & 0.0033 & 13.03 & $<.0001$ \\
\hline $\mathrm{N}$ & 9651 & 4374 & & \\
\hline Miss EPS & -0.0126 & -0.0230 & 4.70 & $<.0001$ \\
\hline $\mathrm{N}$ & 1410 & 6044 & & \\
\hline$\underline{\text { T-stat }}$ & 15.32 & 18.50 & & \\
\hline $\mathrm{p}$-value & $<.0001$ & $<.0001$ & & \\
\hline
\end{tabular}

Notes:

Panel $\mathrm{C}$ of Table 3 displays univariate tests of difference between subsets of firms based on performance. I perform t-tests to determine whether abnormal returns around earnings announcement dates are different based on whether a firm met/missed its' pre-tax and/or after-tax earnings targets. Ab_ret is equal to a firm's 3 -day $(-1,+1)$ cumulative market-adjusted abnormal return. Meet Pre (Miss Pre) is equal to one if a firm's actual pre-tax earnings meet or exceed (do not meet or exceed) the analysts' median pre-tax earnings forecast. Meet EPS (Miss EPS) is equal to one if a firm's actual after-tax earnings meet or exceed (do not meet or exceed) the analysts' median after-tax earnings forecast. T-tests examine the differences between the CARs in a given column or row. 
TABLE 3: The impact of pre-tax earnings forecasts on firm performance evaluation

Panel D: Multivariate analysis of pre-tax earnings as a performance benchmark

$C A R=\beta_{0}+\beta_{4} *$ efe $e_{t}+\beta_{8} *$ prefe $_{t}+\varepsilon$

(Equation 2a)

$C A R=\beta_{0}+\beta_{1} *$ DShortBoth $_{t}+\beta_{2} *$ DShort $_{t}+\beta_{3} *$ DShortP $_{t}+\beta_{4} *$ efe $e_{t}+\beta_{5} *$

$(\text { efe } * D \text { ShortBoth })_{t}+\beta_{6} *(\text { efe } * D S h o r t E)_{t}+\beta_{7} *(\text { efe } * D S h o r t P)_{t}+\beta_{8} *$ prefe $_{t}+\varepsilon$ (Equation $\left.2 \mathrm{~b}\right)$

Variables:

(1)

(2)

(3)

$\begin{array}{lccc}\text { Intercept }\left(\beta_{0}\right) & 0.003 & 0.018 & \left(\beta_{0}+\beta_{1}\right) \\ \text { DShortBoth }\left(\beta_{1}\right) & 5.07 * * * & 21.55 * * * & -11.913 * * * \\ & & -0.041 & \left(\beta_{0}+\beta_{2}\right) \\ \text { DShortE }\left(\beta_{2}\right) & -31.71 * * * & -4.674 * * * \\ & & -0.030 & \left(\beta_{0}+\beta_{3}\right) \\ \text { DShortP }\left(\beta_{3}\right) & -13.62 * * * & 2.02 * * \\ & & -0.015 & \left(\beta_{4}+\beta_{5}\right) \\ \text { EFE }\left(\beta_{4}\right) & 0.043 & -10.72 * * * & 0.943 \\ \text { EFE*DShortBoth }\left(\beta_{5}\right) & 3.28 * * * & 0.400 & \left(\beta_{4}+\beta_{6}\right) \\ \text { EFE*DShortE }\left(\beta_{6}\right) & & 5.6 * * * & 0.009 \\ \text { EFE*DShortP }\left(\beta_{7}\right) & & -0.387 & \left(\beta_{4}+\beta_{7}\right) \\ \text { PFE }\left(\beta_{8}\right) & & -5.45 * * * & 2.52 * *\end{array}$

Notes:

Panel D of Table 3 displays a multivariate analysis of performance evaluation using 3-day CARs (Ab_ret) around earnings announcement dates as the dependent variable. Coefficient estimates, along with t-statistics, are reported. $* * *, * * *$ are indicators of significance at the $10 \%, 5 \%$, and $1 \%$ levels, respectively. Robust errors are clustered by firm. Ab_ret is equal to a firm's 3-day $(-1,+1)$ cumulative market-adjusted abnormal return. DShortBoth is an indicator variable equal to 1 if a firm misses both its' pre- and after-tax earnings forecasts; 0 otherwise. DShortE is an indicator variable equal to 1 if a firm ONLY misses its' after-tax earnings forecasts; 0 otherwise. DShortP is an indicator variable equal to 1 if a firm ONLY misses its' pre-tax earnings forecasts; 0 otherwise. EFE represents the after-tax earnings forecast error equal to actual after-tax earnings per share less the median analyst after-tax earnings per share forecast, scaled by end of year stock price. PFE represents the pre-tax earnings forecast error equal to actual pre-tax earnings per share less the median analyst pre-tax earnings per share forecast, scaled by end of year stock price. 
TABLE 4: The impact of analysts' pre-tax coverage on the transparency of tax-related earnings managemen

Panel A: Descriptive statistics

(1)

(2)

(3)

(4)

Firm-year observations with no analyst pre-tax coverage

\begin{tabular}{|c|c|c|c|c|c|c|c|c|}
\hline Variable & $\underline{\mathbf{N}}$ & Mean & $\underline{\text { Median }}$ & $\underline{\mathbf{N}}$ & Mean & $\underline{\text { Median }}$ & $\underline{\text { T-stat }}$ & Z-stat \\
\hline SA_CAR & 1354 & 0.005 & 0.006 & 663 & 0.011 & 0.008 & $-1.77 *$ & 1.289 \\
\hline Beat w/ Tax & 1354 & 0.366 & 0.000 & 663 & 0.359 & 0.000 & 0.32 & 0.322 \\
\hline $\mathrm{AFE}$ & 1354 & 0.001 & 0.000 & 663 & 0.001 & 0.000 & 1.01 & 0.157 \\
\hline Persistence & 1354 & -3.631 & -0.088 & 663 & -6.376 & 0.064 & 1.17 & $-1.755^{*}$ \\
\hline $\mathrm{BM}$ & 1354 & 0.458 & 0.416 & 663 & 0.379 & 0.340 & $7.04 * * *$ & $6.81 * * *$ \\
\hline Size & 1354 & 7.299 & 7.185 & 663 & 7.057 & 6.896 & $2.87 * * *$ & $2.9 * * *$ \\
\hline Momentum & 1354 & -0.015 & -0.015 & 663 & 0.069 & 0.063 & $-5.74 * * *$ & $-5.9 * * *$ \\
\hline
\end{tabular}

Panel B: Correlations

\begin{tabular}{lcccccccc} 
& Pre & SA_CAR & Beat w/ Tax & AFE & Persistence & BM & Size & Momentum \\
\cline { 2 - 8 } Pre & & $\mathbf{0 . 0 4 0 7}$ & -0.0072 & -0.0216 & -0.0295 & $\mathbf{- 0 . 1 4 4 1}$ & $\mathbf{- 0 . 0 6 3 8}$ & $\mathbf{0 . 1 2 4 2}$ \\
SA_CAR & 0.0287 & & $\mathbf{- 0 . 0 4 3 4}$ & $\mathbf{0 . 1 4 5 6}$ & 0.0081 & $\mathbf{0 . 0 5 2 9}$ & -0.0207 & $\mathbf{- 0 . 1 0 5 3}$ \\
Beat w/ Tax & -0.0072 & $\mathbf{- 0 . 0 3 7 4}$ & & $\mathbf{- 0 . 0 5 2 2}$ & 0.0245 & $\mathbf{0 . 0 6 5 6}$ & $\mathbf{0 . 1 3 1 4}$ & -0.0333 \\
AFE & -0.0035 & $\mathbf{0 . 1 4 5 7}$ & $\mathbf{- 0 . 0 8 0 4}$ & & 0.0261 & $\mathbf{0 . 2 9 4 7}$ & $\mathbf{- 0 . 2 3 2 5}$ & $\mathbf{- 0 . 0 7 1 3}$ \\
Persistence & $\mathbf{0 . 0 3 9 1}$ & $\mathbf{0 . 0 3 7 2}$ & -0.0162 & 0.0010 & & $\mathbf{0 . 0 5 8 7}$ & $\mathbf{0 . 0 4 8 6}$ & -0.0207 \\
BM & $\mathbf{- 0 . 1 5 1 7}$ & 0.0263 & $\mathbf{0 . 0 7 5 1}$ & $\mathbf{0 . 2 0 0 5}$ & -0.0091 & & $\mathbf{- 0 . 0 4 0 3}$ & $\mathbf{- 0 . 2 3 3 1}$ \\
Size & $\mathbf{- 0 . 0 6 4 7}$ & -0.0095 & $\mathbf{0 . 1 2 9 0}$ & $\mathbf{- 0 . 1 8 5 8}$ & -0.0094 & $\mathbf{- 0 . 0 4 5 6}$ & & -0.0243 \\
Momentum & $\mathbf{0 . 1 3 1 3}$ & $\mathbf{- 0 . 1 0 2 8}$ & -0.0366 & -0.0175 & 0.0111 & $\mathbf{- 0 . 1 9 0 0}$ & -0.0121 &
\end{tabular}

Panel A of Table 4 displays descriptive statistics of the sample used to examine the market reaction to tax-related earnings management. *,**,*** are indicators of significance at the $10 \%, 5 \%$, and $1 \%$ levels, respectively. SA_CAR $=$ The cumulative return for the firm for the five trading-day window around the earnings announcement (day -2 to day +2) minus the cumulative return for an equal-weighted portfolio of firms in the same CRSP size decile. Pre is an indicator variable equal to 1 if a firm receives analysts' pre-tax earnings forecast coverage; 0 otherwise. Beat $w /$ tax is an indicator variable equal to 1 if the forecast error without a tax change (AFE w/ETRq3) is less than 0 and the actual forecast error (AFE) is greater than or equal to 0 , and 0 otherwise. Persistence is the firm-specific prior period persistence of the fourth quarter tax component of earnings and equals the estimated coefficient $\beta 1$ from EARN_TAt $+1=\beta+\beta 1 *$ Earnings_ETRq3_TAt $+\beta 2 *$ TCC_TAt $+\varepsilon t+1$ where EARN_TAt +1 represents the annual tax change component of earnings [EARN_TAt+1 $=$ PTEt+1 $(1-\mathrm{ETR} t+1)]$ where PTE is pretax earnings and ETR is the effective tax rate. BM is calculated as common shareholders equity / market value of common stock at the end of the fiscal year. Size equals the natural log of assets at the end of the fiscal year. Momentum equals the cumulative sizeadjusted returns for the six months prior to the earnings announcement, ending on day -3. Column 3 displays the t-statistic examining differences in means while column 4 displays Wilcoxon tests of differences of medians. Panel B of Table 4 displays correlations. Pearson correlations are reported above the diagonal while Spearman correlations are reported below the diagonal. Bold numbers indicated correlations which are significant at the $10 \%$ level. 
TABLE 4: The impact of analysts' pre-tax coverage on the transparency of tax-related earnings management

Panel C: Multivariate analysis

$$
\begin{aligned}
& \text { SA_CAR } A_{i, t}=\beta_{0}+\beta_{1} * \text { Beat } w / \text { tax }_{i, t}+\beta_{2} * A F E_{i, t}+\beta_{3} * \text { Persistence }_{i, t}+\beta_{4} *{\text { Beat } w / \text { Tax } * \text { Persistence }_{i, t}+\beta_{5} * B M_{i, t}}^{\text {(Equation } 3 \mathrm{a})} \\
& +\beta_{6} * \text { Size }_{i, t}+\beta_{7} * \text { Momentum }_{i, t}+\varepsilon_{i, t}
\end{aligned}
$$

Intercept

Pre

Beat $\mathrm{w} / \mathrm{Tax}$

Beat* Pre

AFE

Persistence

Beat $\mathrm{w} / \mathrm{Tax} *$ Persistence

$\mathrm{BM}$

Size

Momentum

N

R-squared
(1)

Pooled

(2)

No Pre-tax forecast

coverage

$-0.002$

$-0.19$

$-0.006$

$-1.77 *$

1.023

$4.23 * * *$

0.000

0.02

0.000

$2.12 * *$

$-0.002$

$-0.19$

0.001

0.68

$-0.021$

$-3.61 * * *$

2017

0.0322
$-0.009$

$-0.86$

-0.003
-0.8

$3.58 * * *$

0.000

$-1.54$

0.000

0.66

$-0.001$

$-0.08$

0.001

1.17

$-0.019$

$-2.84 * * *$

1354

0.0302
(3)

Pre-tax forecast

coverage

0.010

0.69

$-0.83$

0.012

$2.74 * * *$

$-0.003$

$-0.83$

$-0.008$

$-1.29$

10.960

$4.23 * * *$

0.000

0.07

0.000

$2.1 * *$

0.000

$-0.02$

0.001

0.89

$-0.022$

$-3.8 * * *$

2017

0.0362

Notes:

Panel C of Table 4 displays a multivariate analysis of the market reaction to earnings using 5-day size-adjusted CARs (SA_CAR) around earnings announcement dates as the dependent variable. Coefficient estimates, along with t-statistics, are reported. *,**,*** are indicators of significance at the $10 \%, 5 \%$, and $1 \%$ levels, respectively. Robust errors are clustered by firm. SA_CAR $=$ The cumulative return for the firm for the five trading-day window around the earnings announcement (day -2 to day +2 ) minus the cumulative return for an equal-weighted portfolio of firms in the same CRSP size decile. Pre is an indicator variable equal to 1 if a firm receives analysts' pretax earnings forecast coverage; 0 otherwise. Beat $\mathrm{w} / \mathrm{tax}$ is an indicator variable equal to 1 if the forecast error without a tax change (AFE w/ ETRq3) is less than 0 and the actual forecast error (AFE) is greater than or equal to 0 , and 0 otherwise. Persistence is the firmspecific prior period persistence of the fourth quarter tax component of earnings and equals the estimated coefficient $\beta 1$ from EARN_TAt $+1=\beta+\beta 1 *$ Earnings_ETRq3_TAt $+\beta 2 *$ TCC_TAt $+\varepsilon t+1$ where EARN_TAt +1 represents the annual tax change component of earnings [EARN_TAt+1 $=$ PTEt+1 $(1-E T R t+1)]$ where PTE is pretax earnings and ETR is the effective tax rate. BM is calculated as common shareholders equity / market value of common stock at the end of the fiscal year. Size equals the natural log of assets at the end of the fiscal year. Momentum equals the cumulative size-adjusted returns for the six months prior to the earnings announcement, ending on day -3 . 
TABLE 5: Impact of analysts' pre-tax coverage on tax avoidance

Panel A: Descriptive statistics

\begin{tabular}{|c|c|c|c|c|}
\hline Variable & $\underline{\mathbf{N}}$ & Mean & Median & Std Dev \\
\hline ChgETR & $1 \overline{704}$ & -0.009 & -0.002 & 0.140 \\
\hline ChgCETR & 1704 & 0.013 & 0.002 & 0.161 \\
\hline ETR & 1704 & 0.272 & 0.321 & 0.154 \\
\hline CETR & 1704 & 0.184 & 0.177 & 0.158 \\
\hline Size & 1704 & 6.613 & 6.408 & 1.779 \\
\hline ROA & 1704 & 0.045 & 0.068 & 0.167 \\
\hline LEV & 1704 & 0.166 & 0.119 & 0.177 \\
\hline PPE & 1704 & 0.451 & 0.343 & 0.370 \\
\hline INT & 1704 & 0.153 & 0.088 & 0.173 \\
\hline FOR & 1704 & 0.009 & 0.000 & 0.033 \\
\hline
\end{tabular}

Panel B: Correlations

\begin{tabular}{lrrrrrrrrrr} 
& ChgETR & ChgCETR & \multicolumn{1}{c}{ ETR } & \multicolumn{1}{l}{ CETR } & \multicolumn{1}{c}{ SIZE } & \multicolumn{1}{c}{ ROA } & \multicolumn{1}{c}{ LEV } & \multicolumn{1}{c}{ PPE } & \multicolumn{1}{c}{ INT3 } & \multicolumn{1}{c}{ FOR } \\
\cline { 2 - 10 } ChgETR & & $\mathbf{0 . 3 2 0 5}$ & $\mathbf{- 0 . 4 6 4 4}$ & $\mathbf{- 0 . 2 2 8 9}$ & $\mathbf{- 0 . 0 9 9 9}$ & $\mathbf{- 0 . 0 6 9 4}$ & $\mathbf{- 0 . 0 5 2 6}$ & $\mathbf{- 0 . 0 4 2 4}$ & -0.0087 & $\mathbf{- 0 . 0 6 5 7}$ \\
ChgCETR & $\mathbf{0 . 2 8 6 3}$ & & $\mathbf{- 0 . 0 8 4 9}$ & $\mathbf{- 0 . 4 7 2 7}$ & 0.0078 & 0.0382 & -0.0162 & 0.0356 & -0.0014 & -0.0040 \\
ETR & $\mathbf{- 0 . 4 5 1 2}$ & $\mathbf{- 0 . 0 6 9 6}$ & & $\mathbf{0 . 5 7 7 7}$ & $\mathbf{0 . 2 5 1 5}$ & $\mathbf{0 . 5 4 4 3}$ & $\mathbf{0 . 0 6 4 8}$ & $\mathbf{0 . 1 1 1 4}$ & $\mathbf{0 . 1 5 2 3}$ & $\mathbf{0 . 1 6 4 1}$ \\
CETR & $\mathbf{- 0 . 2 3 0 8}$ & $\mathbf{- 0 . 3 7 9 6}$ & $\mathbf{0 . 5 9 2 9}$ & & $\mathbf{0 . 1 5 6 2}$ & $\mathbf{0 . 4 1 1 3}$ & -0.0387 & -0.0318 & $\mathbf{0 . 0 9 7 7}$ & $\mathbf{0 . 1 8 5 5}$ \\
SIZE & $\mathbf{- 0 . 1 2 0 3}$ & -0.0069 & $\mathbf{0 . 2 1 7 7}$ & $\mathbf{0 . 1 9 8 9}$ & & $\mathbf{0 . 2 4 2 4}$ & $\mathbf{0 . 2 9 1 8}$ & $\mathbf{0 . 1 4 5 4}$ & $\mathbf{0 . 1 2 9 4}$ & $\mathbf{0 . 1 4 1 7}$ \\
ROA & $\mathbf{- 0 . 0 8 4 9}$ & $\mathbf{0 . 0 7 3 1}$ & $\mathbf{0 . 4 6 7 5}$ & $\mathbf{0 . 4 9 1 8}$ & $\mathbf{0 . 1 4 7 6}$ & & -0.0353 & $\mathbf{0 . 0 9 3 4}$ & $\mathbf{0 . 0 8 6 6}$ & $\mathbf{0 . 2 4 7 7}$ \\
LEV & $\mathbf{- 0 . 0 7 4 9}$ & -0.0208 & $\mathbf{0 . 1 3 6 8}$ & 0.0307 & $\mathbf{0 . 4 4 0 5}$ & $\mathbf{- 0 . 1 0 8 2}$ & & $\mathbf{0 . 2 9 3 1}$ & $\mathbf{0 . 1 9 7 8}$ & -0.0171 \\
PPE & $\mathbf{- 0 . 0 5 2 4}$ & 0.0265 & $\mathbf{0 . 1 3 0 3}$ & $\mathbf{0 . 0 4 4 3}$ & $\mathbf{0 . 1 4 9 7}$ & $\mathbf{0 . 1 1 0 3}$ & $\mathbf{0 . 3 2 8 7}$ & & $\mathbf{- 0 . 2 7 8 6}$ & 0.0185 \\
INT & $\mathbf{- 0 . 0 7 1 6}$ & -0.0032 & $\mathbf{0 . 1 7 7 7}$ & $\mathbf{0 . 1 5 9 8}$ & $\mathbf{0 . 1 8 0 0}$ & $\mathbf{0 . 0 7 8 4}$ & $\mathbf{0 . 2 2 4 0}$ & $\mathbf{- 0 . 1 8 9 8}$ & & 0.0123 \\
FOR & $\mathbf{- 0 . 1 2 0 9}$ & -0.0390 & $\mathbf{0 . 1 3 2 5}$ & $\mathbf{0 . 2 4 6 1}$ & $\mathbf{0 . 2 3 3 0}$ & $\mathbf{0 . 2 5 9 2}$ & $\mathbf{0 . 0 8 1 6}$ & $\mathbf{0 . 0 6 9 0}$ & $\mathbf{0 . 1 8 0 0}$ &
\end{tabular}

Notes:

Panel A of Table 5 displays descriptive statistics for the sample used to examine the impact of changes in pre-tax earnings coverage on firm-level tax avoidance. 'Chg' indicates the change in the variable from period p- 1 to period $\mathrm{p}$, where p-1 indicates the three-year period ending the year prior to the first year of period $p$. CETR equals the sum of cash taxes paid (TXPD) divided by the sum of pretax income (PI). ETR equals the sum of total tax expense (TXT) divided by the sum pretax income (PI). PRE is an indicator variable equal to 1 if a firm receives analysts' pre-tax earnings forecast coverage; 0 otherwise. NPRE equals the number of analysts issuing pre-tax forecasts for a given firm-year. SIZE equals the natural log of assets at the end of the fiscal year. ROA equals the sum of earnings before tax and special items (PISPI), scaled by total assets. LEV equals long-term debt, scaled by the sum of total assets. PPE equals gross property, plant, and equipment, scaled by the sum of total assets. INT equals intangible assets, scaled by total assets. FOR equals foreign earnings (PIFO), scaled by total assets. Panel B of Table 5 displays correlations. Pearson correlations are reported above the diagonal while Spearman correlations are reported below the diagonal. Bold numbers indicated correlations which are significant at the $10 \%$ level. 
TABLE 5: Impact of analysts' pre-tax earnings coverage on tax avoidance

Panel C: Multivariate analysis

$$
\begin{aligned}
& \Delta \operatorname{CETR}_{i, p}=\beta_{0}+\beta_{1} * C E T R+\beta_{2} * \Delta P R E_{i, p}+\beta_{3} * \Delta \operatorname{Size}_{i, p}+\beta_{4} * \Delta R O A_{i, p}+\beta_{5} * \Delta L E V_{i, p}+\beta_{6} * \Delta P P E_{i, p}+ \\
& \beta_{7} * \Delta I n t_{i, p}+\beta_{8} * \Delta F o r_{i, p}+\varepsilon_{i, p} \\
& \text { (Equation 4) }
\end{aligned}
$$

(2)

(3)

Variable: $\triangle$ CETR $\triangle$ CETR $\Delta$ ETR $\Delta \mathrm{ETR}$

ETR

$-0.444$

$-0.444$

CETR

$-0.529$

$-17.498 * * *$

chgpre

0.025

$3.442 * * *$

chgnpre

chgsize

0.04

$5.147 * * *$

chgroa

$-0.08$

chglev

$-2.111^{* *}$

$-0.088$

$-1.745^{*}$

chgppe

$-0.022$

$-0.708$

chgint

$-0.011$

$-0.232$

chgfor

0.039

0.292

0.166

_cons

$3.841 * * *$

N 1704

R-squared

0.2706

Yes

Year FE

Yes
$-21.183^{* * * *}$

$-0.529$

$-18.17 * * *$

0.004
$3.252 * * *$
0.034
$5.25 * * *$
-0.08
$-2.113 * *$
-0.086
$-1.702 *$
-0.027
-0.823
-0.006
-0.121
0.001
0.01
0.174
$4.098^{* * *}$

0.009

0.686

$\begin{array}{cc} & 0.001 \\ & 1.343 \\ 0.074 & 0.072 \\ 8.663^{* * * *} & 7.435^{* * *} \\ 0.062 & 0.062 \\ 1.681 * & 1.632 \\ -0.077 & -0.076 \\ -3.213 * * * & -3.176 * * * \\ 0.073 & 0.071 \\ 2.341 * * & 2.162 * * \\ 0.013 & 0.015 \\ 0.245 & 0.278 \\ 0.099 & 0.085 \\ 1.2 & 1.057 \\ 0.138 & 0.141 \\ 7.82 * * * & 8.974 * * *\end{array}$

1704

0.2724

1704

1754

0.2851

0.2855

Yes
Yes

Yes
Yes

Yes

Notes:

Panel D of Table 5 displays a multivariate analysis of the impact of changes in pre-tax earnings coverage on firm-level tax avoidance. Coefficient estimates, along with t-statistics, are reported. ***,*** are indicators of significance at the $10 \%, 5 \%$, and $1 \%$ levels, respectively. All regressions cluster errors by both firm and year. Each of the variables is constructed as the average over a three-year period. 'Chg' indicates the change in the variable from period p- 1 to period $\mathrm{p}$, where $\mathrm{p}-1$ indicates the three-year period ending the year prior to the first year of period $p$. CETR equals the sum of cash taxes paid (TXPD) divided by the sum of pretax income (PI) in period p-1. ETR equals the sum of total tax expense (TXT) divided by the sum pretax income (PI) in period p-1. PRE is an indicator variable equal to 1 if a firm receives analysts' pre-tax earnings forecast coverage; 0 otherwise. NPRE equals the number of analysts issuing pre-tax forecasts for a given firm-year. SIZE equals the natural $\log$ of assets at the end of the fiscal year. ROA equals the sum of earnings before tax and special items (PI-SPI), scaled by total assets. LEV equals long-term debt, scaled by the sum of total assets. PPE equals gross property, plant, and equipment, scaled by the sum of total assets. INT equals intangible assets, scaled by total assets. FOR equals foreign earnings (PIFO), scaled by total assets. 


\section{REFERENCES}

Bartov, E., D. Givoly, and C. Hayn. 2002. The rewards to meeting or beating earnings expectations. Journal of Accounting and Economics. Vol. 33: 173-204.

Blaylock. B., T. Shevlin, and R. Wilson. 2012. Tax Avoidance, Large Positive Temporary Book-Tax Differences, and Earnings Persistence. The Accounting Review. Vol. 87: 91-120.

Bradshaw, M. 2011. Analysts' Forecasts: What Do We Know after Decades of Work? Working Paper.

Brown, J. and K. Drake. 2012. Network ties among low-tax firms. Working Paper.

Brown, L., P. Griffin, R. Hagerman, and M. Zmijewski. 1987. Security analyst superiority relative to univariate time-series models in forecasting quarterly earnings. Journal of Accounting and Economics. Vol. 9: 61-87.

Call, A., S. Chen, and Y. Tong. 2009. Are analysts' earnings forecasts more accurate when accompanied by cash flow forecasts? Review of Accounting Studies. Vol. 14: 358-391.

Call, A., S. Chen, and Y. Tong. 2012 Are analysts' cash flow forecasts naïve extensions of their own earnings forecasts? Contemporary Accounting Research. Forthcoming.

Chen, K. and M. Schoderbek. 2000. The 1993 tax rates increase and deferred tax adjustments: A test of functional fixation. Journal of Accounting Research. Vol. 38: 23-45.

Cook, K., G. Huston, and T. Omer. 2008. Earnings Management through Effective Tax Rates: The Effects of Tax-Planning Investment and the Sarbanes-Oxley Act of 2002. Contemporary Accounting Research. Vol. 25: 447-471.

Dechow, P. and D. Skinner. 2000. Earnings Management: Reconciling the Views of Accounting Academics, Practitioners, and Regulators. Working Paper.

DeFond, M. and M. Hung. 2003. An empirical analysis of analysts' cash flow forecasts. Journal of Accounting and Economics. Vol. 35: 73-100.

Dhaliwal, D., C. Gleason, and L. Mills. 2004. Last-Chance Earnings Management: Using the Tax Expense to Meet Analysts' Forecasts. Contemporary Accounting Research. Vol. 21: 431-459. 
Drake, K. 2012. Does Firm Life Cycle Explain the Relation Between Book-Tax Differences and Earnings Persistence? Working Paper.

Dyreng, S. 2007. The Cost of Private Debt Covenant Violation. Working Paper.

Dyreng, S., M. Hanlon, and E. Maydew. 2008. Long-run corporate tax avoidance. The Accounting Review. Vol. 83: 61-82.

Ertimur, Y., J. Livnat, and M. Martikainen. 2003. Differential Market Reactions to Revenue and Expense Surprises. Review of Accounting Studies. Vol. 8: 185-211.

Ertimur, Y., W. Mayew, and S. Stubben. 2011. Analyst reputation and the issuance of disaggregated earnings forecasts to I/B/E/S. Review of Accounting Studies. Vol. 16: 29-58.

Fama, E. and K. French. 1992. The cross-section of expected stock returns. Journal of Finance. Vol. 47: 427-465.

Ford Motor Company. Jan. 27, 2012. http://corporate.ford.com/news-center/pressreleases-detail/pr-ford-posts-2011-pretax-operating-35878

Gaertner, F. 2011. CEO After-Tax Compensation Incentives and Corporate Tax Avoidance. Working Paper.

Givoly, D., C. Hayn, and R. Lehavy. 2009. The Quality of Analysts' Cash Flow Forecasts. The Accounting Review. Vol. 84: 1877-1911.

Gleason, C. and C. Lee. 2003. Analyst Forecast Revisions and Market Price Discovery. The Accounting Review. Vol. 78: 193-225.

Gleason, C., and L. Mills. 2008. Evidence of differing market responses to beating analysts' targets through tax expense decreases. Review of Accounting Studies. Vol. 13: 295-318.

Graham, J., J. Raedy, and D. Shackelford. 2012. Research in accounting for income taxes. Journal of Accounting and Economics. Vol. 53: 412-434.

Gupta, S. and K. Newberry. 1997. Detrminants of the variability in corporate effective tax rates: Evidence from longitudinal data. Journal of Accounting and Public Policy. Vol 16: 1-34.

Hanlon, M. 2005. The Persistence and Pricing of Earnings, Accruals, and Cash Flows When Firms Have Large Book-Tax Differences. The Accounting Review. Vol. 80: $137-166$. 
Hanlon, M. and S. Heitzman. 2010. A review of tax research. Journal of Accounting and Economics. Vol. 50: 127-178.

Hanlon, M., L. Mills, and J. Slemrod. 2005. An empirical examination of corporate tax noncompliance. Taxing Corporate income in the $21^{\text {st }}$ Century: Cambridge University Press.

Hoopes, J., D. Mescall, and J. Pittman. 2012. Do IRS Audits Deter Corporate Tax Avoidance? The Accounting Review. Forthcoming.

Kasznik, R. and M. McNichols. 2002. Does Meeting Earnings Expectations Matter? Evidence from Analyst Forecast Revisions and Share Prices. Journal of Accounting Research. Vol. 40: 727-759.

Keung, E. 2010. Do Supplementary Sales Forecasts Increase the Credibility of Financial Analysts' Earnings Forecasts? The Accounting Review. Vol. 85: 2047-2074.

Koh, K., D.A. Matsumoto, and S. Rajgopal. 2008. Meeting or Beating Analyst Expectations in the Post-Scandals World: Changes in Stock Market Rewards and Managerial Actions. Contemporary Accounting Research. Vol. 25: 1067-1098.

Lipe., R. 1986. The Information Contained in the Components of Earnings. Journal of Accounting Research. Vol. 24: 37-64.

McInnis, J. and D. Collins. 2011. The Effect of Cash Flow Forecasts on Accrual Quality and Benchmark Beating. Journal of Accounting and Economics. Vol. 51: 219239.

Plumlee, M. 2003. The Effect of Information Complexity on Analysts' Use of That Information. The Accounting Review. Vol. 78: 275-296.

Ramnath, S., S. Rock, and P. Shane. 2008. The financial analyst forecasting literature: A taxonomy with suggestions for further research. International Journal of Forecasting. Vol. 24: 34-75.

Rees, L. and K. Sivaramakrishnan. 2007. The Effect of Meeting or Beating Revenue Forecasts on the Association between Quarterly Returns and Earnings Forecasts Errors. Contemporary Accounting Research. Vol. 24: 259-290.

Robinson, L. 2010. Do Firms Incur Costs to Avoid Reducing Pre-Tax Earnings? Evidence from the Accounting for Low-Income Housing Tax Credits. The Accounting Review. Vol. 85: 637-669. 
Schmidt, A. 2006. The Persistence, Forecasting, and Valuation Implications of the Tax Change Component of Earnings. The Accounting Review. Vol. 81: 589-616.

Shackelford, D. and T. Shevlin. 2001. Empirical tax research in accounting. Journal of Accounting and Economics. Vol. 31: 321-387.

Thomas, J. and F. Zhang. 2011. Tax Expense Momentum. Journal of Accounting Research. Vol. 49: 791-821.

Weisbach, D. 2002. Ten Truths about tax shelters. 55 Tax L. Rev. 215. 